\title{
Synthesis and photovoltaic properties of a series of bulk heterojunction solar cells based on interchain-linked conjugated polymers
}

\author{
Rong-Ho Lee ${ }^{1}$, Wei-Yu Chen ${ }^{2}$ and Sheng-Yi Shiau ${ }^{1}$ \\ We have used Suzuki coupling to synthesize a series of maleimide-thiophene copolymers presenting pendent 2-hydroxyethyl \\ and 6-hydroxyhexyl units. The maleimide-thiophene copolymers containing different contents of $\mathrm{OH}$ groups were then reacted \\ with 3,3'-dimethoxy-4,4'-biphenylene diisocyanate (DMBPI) in solution to form the interchain-linked polymers. The interchain- \\ linked polymers exhibited excellent solubility in organic solvents. The average molecular weight and thermal stability of the \\ copolymers increased after interchain linking with DMBPI. The wavelengths of maximum absorption of the interchain-linked \\ copolymers were red-shifted relative to those of the corresponding side-chain copolymers. The energy level of the lowest \\ unoccupied molecular orbitals and highest occupied molecular orbitals decreased after the copolymers had undergone \\ interchain linking with DMBPI. We fabricated polymer solar cells (PSCs) from blends of the interchain-linked copolymers and \\ $[6,6]$-phenyl- $\mathrm{C}_{61}$-butyric acid methyl ester. The photovoltaic performances of the PSCs incorporating the interchain-linked \\ copolymers were superior to those of the corresponding PSCs based on the $\mathrm{OH}$-presenting copolymers.
}

Polymer Journal (2013) 45, 744-757; doi:10.1038/pj.2012.212; published online 5 December 2012

Keywords: fullerene derivative; maleimide-thiophene copolymer; polymer solar cell

\section{INTRODUCTION}

The development of novel low-band gap $\pi$-conjugated polymers is an attractive research area because bulk heterojunction polymer solar cells (PSCs) incorporating them can be fabricated at low cost with large areas, flexible shapes, light weight and solution processability. ${ }^{1-6}$ The photoactive layer in most bulk heterojunction cells is based on a blend of an electron-donor conjugated polymer and an electronacceptor fullerene derivative, typically $[6,6]$-phenyl- $\mathrm{C}_{61}$-butyric acid methyl ester (PCBM). Several recent efforts have focused on the synthesis of a new low-band gap conjugated polymers that improve the absorption of solar radiation and increase charge mobilities. ${ }^{7-20}$ In addition to the intrinsic characteristics of the polymer, the amount of PCBM in the blend, ${ }^{17,18}$ the compatibility of the polymer and PCBM, the morphology of the photoactive layer ${ }^{19-21}$ and the deviceprocessing conditions all have important roles affecting the photovoltaic (PV) performance of PSCs. ${ }^{8-10,22,23}$ Photo-energy conversion efficiencies $(\eta)$ of $>7 \%$ have been achieved for PSCs based on blends of poly(thiophene) derivatives and fullerene derivatives. $^{7-10,24,25}$

In addition to the short-circuit current densities $\left(J_{S C}\right)$ and values of $\eta$ that are typically measured, recent investigations have also been made into optimizing the PV efficiency stability of PSCs. For example, incorporation of a ultraviolet (UV) shielding layer into a PSC can protect the cell from damage caused by UV light and enhance the operational stability. ${ }^{26,27}$ Inserting the buffer layer $(\mathrm{ZnO}, \mathrm{MnO}$, $\mathrm{Cs}_{2} \mathrm{CO}_{3}$ or $\mathrm{Al}_{2} \mathrm{O}_{3}$ thin film) at the interface between the electrode and the photoactive layer can not only prevent the $\mathrm{O}_{2} / \mathrm{H}_{2} \mathrm{O}$-induced degradation of the PSC but also provide a larger electron extraction interface and, therefore, an enhanced photocurrent density. ${ }^{28-32}$ In addition, the PV performance is strongly related to the morphology of the active layer based on a conjugated polymer/PCBM blend. Some approaches have been tested to control the nanoscale film morphologies of polymer/PCBM blends. ${ }^{33-36}$ The addition of a compatibilizer to suppress large-scale phase separation of the polymer/PCBM blend can enhance the long-term thermal stability of the cell performance. ${ }^{33}$ Incorporating electron acceptors with high mobility in the polymer/PCBM blend film can result in highly balanced electron and hole mobilities, thereby enhancing the PV performance of the PSC. ${ }^{34}$ Light- or solvent-soaking to tailor the morphology of the active layer is another potential approach toward improving the PV stabilities of PSCs. ${ }^{35,36}$ On the other hand, decreased PV efficiency stability is closely related to the degree of thermally induced aggregation of the polymer chains and PCBM units. ${ }^{37-39}$ Thermally crosslinkable fullerene derivatives have been used to improve the thermal stabilities of PSCs by chemically fixing the optimized morphology of the photoactive layer. ${ }^{40-44}$ Moreover,

${ }^{1}$ Department of Chemical Engineering, National Chung Hsing University, Taichung, Taiwan and ${ }^{2}$ Department of Chemical and Materials Engineering, National Yunlin University of Science and Technology, Yunlin, Taiwan

Correspondence: Professor R-H Lee, Department of Chemical Engineering, National Chung Hsing University, 250 Kuo-Kuang Road, Taichung 402, Taiwan.

E-mail: rhl@.nchu.edu.tw.

Received 28 June 2012; revised 2 October 2012; accepted 26 October 2012; published online 5 December 2012 
photo-crosslinkable polythiophene derivatives have also been developed to stabilize the thin-film morphology of the photoactive layer, thereby enhancing the stability of PSCs. ${ }^{45-47}$ In addition, new PSCs fabricated from the thermal-crosslinked polymers have been reported to possess enhanced morphological stability. ${ }^{48,49}$

In this study, we synthesized a series of maleimide-thiophene copolymers containing different contents of $\mathrm{OH}$ groups, which we then interchain-linked with 3,3'-dimethoxy-4,4'-biphenylene diisocyanate (DMBPI) to form lightly crosslinked copolymers. Here, DMBPI plays the role of a chain extender of the copolymers. The average molecular weights of the copolymers were enhanced after forming the bridge links with DMBPI. We anticipated higher thermal stability and better thin-film formability for the interchain-linked copolymers relative to those of their corresponding $\mathrm{OH}$ grouppresenting side-chain copolymers. ${ }^{50}$ The PV performance of the $\mathrm{OH}$ group-containing side-chain maleimide-thiophene copolymers has been reported by us previously. ${ }^{50}$ However, PV properties of the PSCs fabricated from these $\mathrm{OH}$ group-containing side-chain maleimide-thiophene copolymers were poor owing to low molecular weight and poor thin-film quality of the copolymers. The improvement of the thin-film formability and the stability of the polythiophene derivatives by the interchain-linking based on the diisocyanate chemistry has not been reported before even though the photo- and thermal-crosslinkable polythiophene derivatives have been developed to enhance the thermal stability of the photoactive layer. We fabricated a series of PSCs from the blends of the copolymers (either $\mathrm{OH}$ group-presenting side-chain copolymers or interchain-linked copolymers) with the fullerene derivative PCBM. Maleimide polymers are well-established red emitters in polymer light-emitting devices. ${ }^{51,52}$ Moreover, a low-band gap polymer providing high charge mobility is a good choice for use as the electron-donating polymer when preparing PSCs exhibiting efficient photon-to-charge conversion. Therefore, we chose maleimide-thiophene copolymers as electron-donating polymers for our PSCs. We expected the PV performance and operational stability of the PSCs to be enhanced by the presence of the DMBPI bridge links between the backbones of the maleimide-thiophene copolymers. We used UV-visible (Vis) absorption spectroscopy and cyclic voltammetry to study the effects of the DMBPI bridge links on the photophysical and electrochemical behavior, respectively, of the copolymers. We also used atomic force microscopy (AFM) to study the morphologies of the $\mathrm{OH}$-functionalized copolymer/PCBM and interchain-linked maleimide-thiophene copolymer/PCBM blends. Herein, we also discuss the influence of the functionality and the degree of DMBPI bridge linking on the morphologies and PV performances of PSCs based on these maleimide-thiophene copolymer/PCBM blends.

\section{EXPERIMENTAL PROCEDURE}

\section{Synthesis of maleimide-thiophene copolymers}

All reactions and manipulations were performed under a $\mathrm{N}_{2}$ atmosphere using standard Schlenk techniques. Chromatographic separations were performed through silica gel. All chemicals were purchased in reagent grade from Aldrich (St Louis, MO, USA), Fluka (Buchs SG, Switzerland) or RDH Chemical (Seelze, Germany). $N$-(2'-ethylhexyl)-bis(4-bromophenyl)maleimide (1), N-2-(tetrahydro-2H-pyran-2-yloxy)ethyl-3,4-dibromophenyl maleimide (2) and 2,5bis (4,4,5,5-tetramethyl-1,3,2-dioxaborolan-2-yl)thiophene (4) were synthesized as described previously. ${ }^{50}$ Scheme 1 details the syntheses of the maleimidethiophene copolymers TM2C41-OH-TM6C21-OH containing 2-hydroxyethyl and 6-hydroxyhexyl units. The copolymers TM2C41-P, TM2C21-P, TM2C41$\mathrm{OH}$ and $\mathrm{TM} 2 \mathrm{C} 21-\mathrm{OH}$ were synthesized as described previously. ${ }^{50,53}$ All of the polymers were prepared through palladium-catalyzed Suzuki coupling polymerization. As displayed in the Scheme 2, the maleimide-thiophene copolymers containing different contents of $\mathrm{OH}$ groups were reacted with DMBPI to form the interchain-linked polymers CTM2C41-CTM6C21. ${ }^{54}$ The chemical structures of the conjugated polymers were characterized using proton nuclear magnetic resonance $\left({ }^{1} \mathrm{H}-\mathrm{NMR}\right)$ spectroscopy. The average molecular weights of the polymers were characterized using gel permeation chromatography.

\section{N-6-(tetrahydro-2H-pyran-2-yloxy)hexyl-3, 4-dibromophenyl maleimide (3)}

Bis(4-bromophenyl)maleimide $(2.80 \mathrm{~g}, 6.90 \mathrm{mmol})$ was treated with potassium tert-butoxide $(1.54 \mathrm{~g}, 13.8 \mathrm{mmol})$ in dimethylformamide $(20 \mathrm{ml})$ at $0{ }^{\circ} \mathrm{C}$. After $2 \mathrm{~h}$ of stirring, 2-(6-bromohexyloxy)tetrahydro-2H-pyran (1.81 g, $13.8 \mathrm{mmol})$ was added to the solution, which was then stirred at room temperature for $10 \mathrm{~h}$. After evaporating the volatiles under reduced pressure, the residue was dissolved in EtOAc and washed with water. The organic phase was dried and concentrated. The desired product was isolated through column chromatography (EtOAc/hexanes) as a yellow liquid $(2.8 \mathrm{~g}, 69 \%) .{ }^{1} \mathrm{H}-\mathrm{NMR}(600 \mathrm{MHz}$, $\left.\mathrm{CDCl}_{3}\right): \delta 1.30-1.42(\mathrm{~m}, 8 \mathrm{H}), 1.44-1.58(\mathrm{~m}, 4 \mathrm{H}), 1.65-1.80(\mathrm{~m}, 2 \mathrm{H}), 3.72$ $(\mathrm{t}, 2 \mathrm{H}), 3.81(\mathrm{t}, 2 \mathrm{H}), 3.94(\mathrm{t}, 2 \mathrm{H}), 4.54(\mathrm{t}, 1 \mathrm{H}), 7.34(\mathrm{~d}, 4 \mathrm{H})$ and 7.48 (d, 4H) p.p.m. Anal. Calcd. for $\mathrm{C}_{27} \mathrm{H}_{29} \mathrm{NO}_{4} \mathrm{Br}_{2}$ : C, $54.6 \% ; \mathrm{H}, 4.98 \%$; , $10.90 \%$; and N, 2.37\%. Found: C, 53.9\%; H, 4.93\%; O, 11.03\%; and N, $2.54 \%$.

\section{Copolymer TM6C41-OH}

Compounds 1 (0.62 g, $1.2 \mathrm{mmol}), 3(0.17 \mathrm{~g}, 0.30 \mathrm{mmol}), 4(0.50 \mathrm{~g}, 1.5 \mathrm{mmol})$ and $\mathrm{Pd}\left(\mathrm{PPh}_{3}\right)_{4}(0.020 \mathrm{~g}, 0.017 \mathrm{mmol})$ were dissolved in a mixture of toluene $(10 \mathrm{ml})$ and aqueous $\mathrm{K}_{2} \mathrm{CO}_{3}(1.38 \mathrm{~g})$ in $\mathrm{H}_{2} \mathrm{O}(5 \mathrm{ml})$. The solution was heated under reflux with vigorous stirring for $24 \mathrm{~h}$. Next, the end-capper, 4-bromotoluene $(0.58 \mathrm{ml}, 3.4 \mathrm{mmol})$, was added, together with additional $\mathrm{Pd}\left(\mathrm{PPh}_{3}\right)_{4}$, and then the reaction mixture was heated under reflux for a further $24 \mathrm{~h}$. After cooling to room temperature, the volatiles were evaporated under reduced pressure and the aqueous residue extracted with toluene. The combined extracts were dried $\left(\mathrm{MgSO}_{4}\right)$, filtered and concentrated to yield the polymer TM6C41-P, which was dissolved in tetrahydrofuran (THF). Thirty-seven percent $\mathrm{HCl}(5 \mathrm{ml})$ was added dropwise to the polymer solution, which was then heated under reflux for $12 \mathrm{~h}$. After cooling to room temperature, the volatiles were evaporated under reduced pressure. The residue was dissolved in a small amount of THF and precipitated with $\mathrm{MeOH} / \mathrm{H}_{2} \mathrm{O}\left(10: 1\left(\mathrm{vv}^{-1}\right)\right)$; this procedure was repeated several times. The purified polymer was filtered and dried under vacuum to yield a red solid powder $(0.55 \mathrm{~g}, 48 \%) . M_{\mathrm{n}}=1.92 \mathrm{~kg} \mathrm{~mol}^{-1} ; M_{\mathrm{w}}=4.28 \mathrm{~kg} \mathrm{~mol}^{-1} .{ }^{1} \mathrm{H}-\mathrm{NMR}$ $\left(600 \mathrm{MHz}, \mathrm{CDCl}_{3}\right): \delta 0.80-0.95(\mathrm{~m}, 24 \mathrm{H}), 1.15-1.45(\mathrm{~m}, 32 \mathrm{H}), 1.46-1.64(\mathrm{~m}$, $8 \mathrm{H}), 1.74-1.84(\mathrm{~m}, 4 \mathrm{H}), 3.50-3.56(\mathrm{~d}, 8 \mathrm{H}), 3.61-3.67(\mathrm{~m}, 4 \mathrm{H}), 7.32-7.41(\mathrm{~m}$, $40 \mathrm{H})$ and 7.47-7.64 (m, 10H) p.p.m. Anal. Calcd. for $\left[\left(\mathrm{C}_{28} \mathrm{H}_{27} \mathrm{NO}_{2} \mathrm{~S}\right)_{4}\left(\mathrm{C}_{26} \mathrm{H}_{23-}\right.\right.$ $\mathrm{NO}_{3} \mathrm{~S}$ )]: C, $75.50 \% ; \mathrm{H}, 5.98 \% ; \mathrm{O}, 8.08 \% ; \mathrm{N}, 3.17 \%$; and S, 7.27\%. Found: C, $74.9 \%$; H, 5.87\%; O, $8.38 \%$; N, 3.27\%; and S, $7.20 \%$.

\section{Copolymer TM6C21-OH}

The reaction of $1(0.514 \mathrm{~g}, 1.0 \mathrm{mmol}), 3(0.290 \mathrm{~g}, 0.5 \mathrm{mmol}), 4(0.500 \mathrm{~g}$, $1.50 \mathrm{mmol}), \mathrm{Pd}\left(\mathrm{PPh}_{3}\right)_{4}(0.020 \mathrm{~g}, 0.017 \mathrm{mmol}), \mathrm{K}_{2} \mathrm{CO}_{3}(1.38 \mathrm{~g}), \mathrm{H}_{2} \mathrm{O}(2 \mathrm{ml})$ and 4-bromotoluene $(0.58 \mathrm{ml}, 3.4 \mathrm{mmol})$ was performed using the same procedure as that described above for TM6C41-P to provide a red solid powder $(0.42 \mathrm{~g}$, $34 \%) . M_{\mathrm{n}}=2.15 \mathrm{~kg} \mathrm{~mol}^{-1} ; M_{\mathrm{w}}=3.87 \mathrm{~kg} \mathrm{~mol}^{-1} .{ }^{1} \mathrm{H}-\mathrm{NMR}\left(600 \mathrm{MHz}, \mathrm{CDCl}_{3}\right)$ : $\delta 0.80-0.95(\mathrm{~m}, 12 \mathrm{H}), 1.15-1.45(\mathrm{~m}, 16 \mathrm{H}), 1.46-1.64(\mathrm{~m}, 8 \mathrm{H}), 1.74-1.84(\mathrm{~m}$, $2 \mathrm{H}), 3.50-3.56(\mathrm{~d}, 4 \mathrm{H}), 3.61-3.67(\mathrm{~m}, 4 \mathrm{H}), 7.32-7.41(\mathrm{~m}, 24 \mathrm{H})$ and $7.47-7.64$ (m, 6H) p.p.m. Anal. Calcd. for $\left[\left(\mathrm{C}_{28} \mathrm{H}_{27} \mathrm{NO}_{2} \mathrm{~S}\right)_{2.16}\left(\mathrm{C}_{26} \mathrm{H}_{23} \mathrm{NO}_{3} \mathrm{~S}\right)\right]$ : C, $75.21 \%$; H, 5.79\%; O, 8.48\%; N, 3.20\%; and S, 7.32\%. Found: C, 75.30\%; H, 5.62\%; O, $8.57 \%$; N, $3.12 \%$; and $\mathrm{S}, 7.10 \%$

\section{CTM2C41}

TM2C $41-\mathrm{OH}(0.2 \mathrm{~g}, 27.4 \mu \mathrm{mol})$ and DMBPI $(8.1 \mathrm{mg}, 27.4 \mu \mathrm{mol})$ were dissolved in a mixture of anhydrous THF and dimethylformamide (10:1 $\left.\left(\mathrm{vv}^{-1}\right) ; 30 \mathrm{ml}\right)$ under a $\mathrm{N}_{2}$ atmosphere..$^{51}$ The solution was heated under reflux with vigorous stirring for $6 \mathrm{~h}$. After cooling to room temperature, the volatiles were evaporated under reduced pressure. The residue was dissolved in a small amount of THF and precipitated with $\mathrm{MeOH}$; this procedure was repeated several times. The purified polymer was filtered and dried under vacuum to 


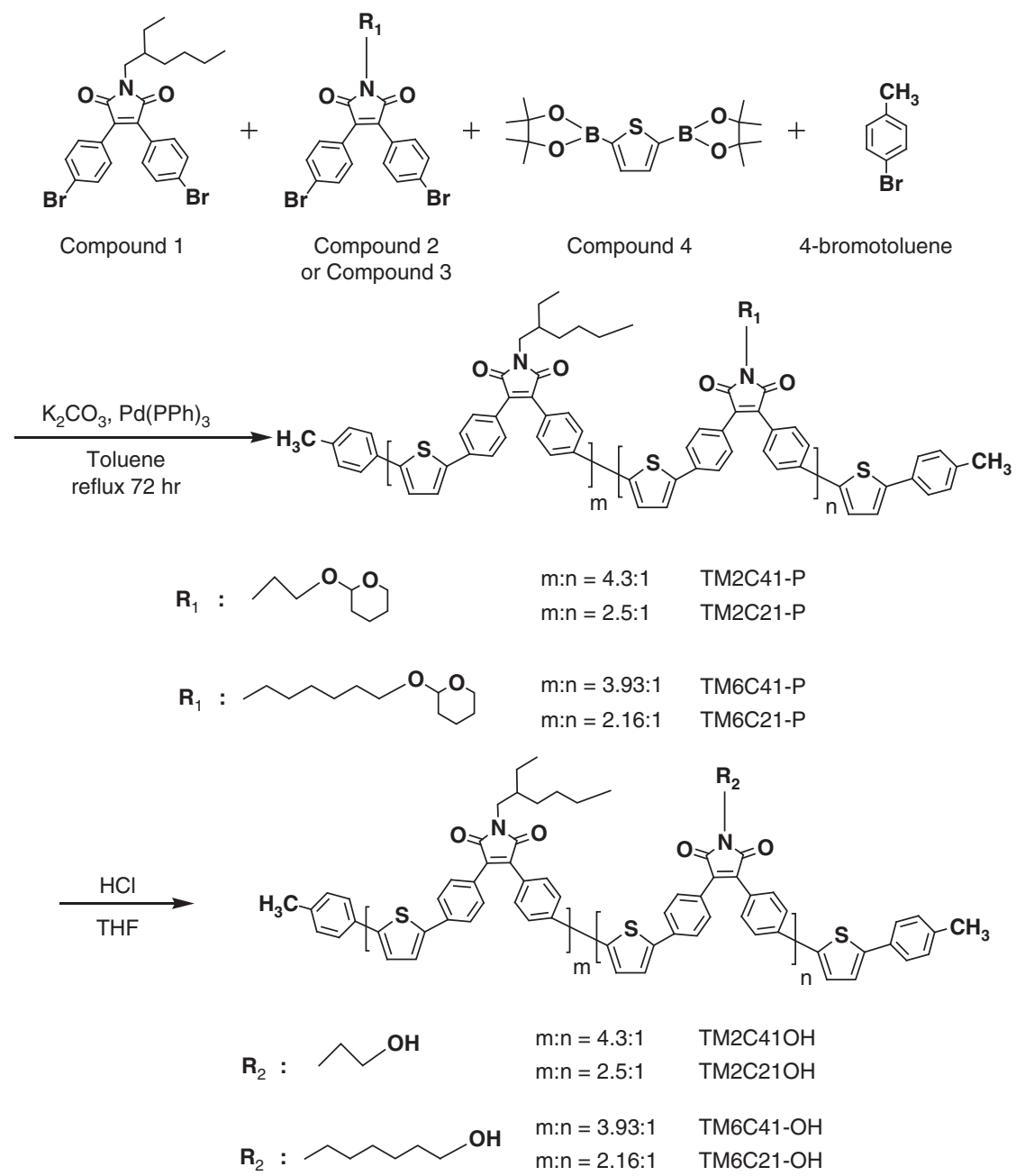

Scheme 1 Synthesis of the maleimide-thiophene copolymers TM2C41-OH, TM2C21-OH, TM6C41-OH and TM6C21-OH.

yield a red solid powder $(0.16 \mathrm{~g}) . M_{\mathrm{n}}=5.29 \mathrm{~kg} \mathrm{~mol}^{-1} ; M_{\mathrm{w}}=8.41 \mathrm{~kg} \mathrm{~mol}^{-1}$. ${ }^{1} \mathrm{H}-\mathrm{NMR}\left(600 \mathrm{MHz}, \mathrm{CDCl}_{3}\right): \delta 0.80-1.0(\mathrm{~m}, 24 \mathrm{H}), 1.20-1.40(\mathrm{~m}, 35 \mathrm{H}), 1.75$ $1.83(\mathrm{~m}, 4 \mathrm{H}), 3.55(\mathrm{~d}, 8 \mathrm{H}), 3.85-3.92(\mathrm{~m}, 4 \mathrm{H}), 7.1(\mathrm{~d}, 2 \mathrm{H}), 7.2-7.5(\mathrm{~m}, 10 \mathrm{H})$ and 7.5-7.7 (m, 20H) p.p.m.

\section{CTM2C21}

The reaction of TM2C21-OH $(0.2 \mathrm{~g}, 33 \mu \mathrm{mol})$ and DMBPI $(9.8 \mathrm{mg}, 33 \mu \mathrm{mol})$ was performed using the same procedure as that described above for CTM2C41. The purified polymer was filtered and dried under vacuum to yield a red solid powder $(0.17 \mathrm{~g}) . M_{\mathrm{n}}=5.94 \mathrm{~kg} \mathrm{~mol}^{-1} ; M_{\mathrm{w}}=8.26 \mathrm{~kg} \mathrm{~mol}^{-1}$. ${ }^{1} \mathrm{H}-\mathrm{NMR}\left(600 \mathrm{MHz}, \mathrm{CDCl}_{3}\right): \delta 0.80-1.0(\mathrm{~m}, 15 \mathrm{H}), 1.20-1.40(\mathrm{~m}, 23 \mathrm{H}), 1.75-$ $1.83(\mathrm{~m}, 2.5 \mathrm{H}), 3.58(\mathrm{~d}, 5 \mathrm{H}), 3.80-3.92(\mathrm{~m}, 3 \mathrm{H}), 7.05(\mathrm{~d}, 2 \mathrm{H}), 7.2-7.5(\mathrm{~m}$, $10 \mathrm{H})$ and $7.5-7.7(\mathrm{~m}, 20 \mathrm{H})$ p.p.m.

\section{CTM6C41}

The reaction of TM6C41-OH $(0.2 \mathrm{~g}, 46.7 \mu \mathrm{mol})$ and DMBPI $(14 \mathrm{mg}$, $46.7 \mu \mathrm{mol}$ ) was performed using the same procedure as that described above for CTM2C41. The purified polymer was filtered and dried under vacuum to yield a red solid powder $(0.15 \mathrm{~g}) . M_{\mathrm{n}}=2.92 \mathrm{~kg} \mathrm{~mol}^{-1} ; M_{\mathrm{w}}=4.64 \mathrm{~kg} \mathrm{~mol}^{-1}$. ${ }^{1} \mathrm{H}-\mathrm{NMR}\left(600 \mathrm{MHz}, \mathrm{CDCl}_{3}\right): \delta 0.80-0.95(\mathrm{~m}, 24 \mathrm{H}), 1.15-1.45(\mathrm{~m}, 32 \mathrm{H}), 1.46-$ $1.64(\mathrm{~m}, 8 \mathrm{H}), 1.74-1.84(\mathrm{~m}, 4 \mathrm{H}), 3.50-3.56(\mathrm{~d}, 8 \mathrm{H}), 3.61-4.00(\mathrm{~m}, 4 \mathrm{H}), 6.95-$ $7.2(\mathrm{~m}, \mathrm{nH}), 7.32-7.41(\mathrm{~m}, 10 \mathrm{H})$ and $7.47-7.64(\mathrm{~m}, 40 \mathrm{H})$ p.p.m.

\section{CTM6C21}

The reaction of TM6C21-OH $(0.2 \mathrm{~g}, 35 \mu \mathrm{mol})$ and DMBPI $(10 \mathrm{mg}, 35 \mu \mathrm{mol})$ was performed using the same procedure as that described above for CTM2C21. The purified polymer was filtered and dried under vacuum to yield a red solid powder $(0.18 \mathrm{~g}) . M_{\mathrm{n}}=3.85 \mathrm{~kg} \mathrm{~mol}^{-1} ; M_{\mathrm{w}}=5.70 \mathrm{~kg} \mathrm{~mol}^{-1}$. ${ }^{1} \mathrm{H}-\mathrm{NMR}\left(600 \mathrm{MHz}, \mathrm{CDCl}_{3}\right): \delta 0.80-0.95(\mathrm{~m}, 12 \mathrm{H}), 1.15-1.45(\mathrm{~m}, 16 \mathrm{H}), 1.46-$ $1.64(\mathrm{~m}, 8 \mathrm{H}), 1.74-1.84(\mathrm{~m}, 2 \mathrm{H}), 3.50-3.56(\mathrm{~d}, 4 \mathrm{H}), 3.61-4.00(\mathrm{~m}, 4 \mathrm{H}), 6.95-$ $7.20(\mathrm{~m}, \mathrm{nH}), 7.32-7.41(\mathrm{~m}, 6 \mathrm{H})$ and $7.47-7.64(\mathrm{~m}, 24 \mathrm{H})$ p.p.m.

\section{Instruments}

${ }^{1} \mathrm{H}-\mathrm{NMR}$ spectra were recorded using a Bruker AMX-600 MHz spectrometer (Bruker Co., Billerica, MA, USA). Elemental analysis was performed using an elemental analyzer (Elementar Vario EL III; Hanau, Germany). Gel permeation chromatography was performed using a Waters chromatography system (Waters 717 Plus Autosampler, Waters Co., Milford, MA, USA), two Waters Styragel linear columns, polystyrene as the standard and THF as the eluent. Glass transition temperatures $\left(T_{\mathrm{g}}\right)$ were measured under a $\mathrm{N}_{2}$ atmosphere using a differential scanning calorimeter (DSC-2010; TA Instruments, New Castle, DE, USA) operated at a heating rate of $10^{\circ} \mathrm{C} \mathrm{min}{ }^{-1}$. Thermogravimetric analysis was performed under a $\mathrm{N}_{2}$ atmosphere using a thermogravimetric analyzer (TGA-2050; TA Instruments) operated at a heating rate of $10^{\circ} \mathrm{Cmin}^{-1}$. UV-Vis spectra were recorded using a Hewlett-Packard 8453 spectrophotometer (Hewlett-Packard Taiwan Co., Taipei, Taiwan). 


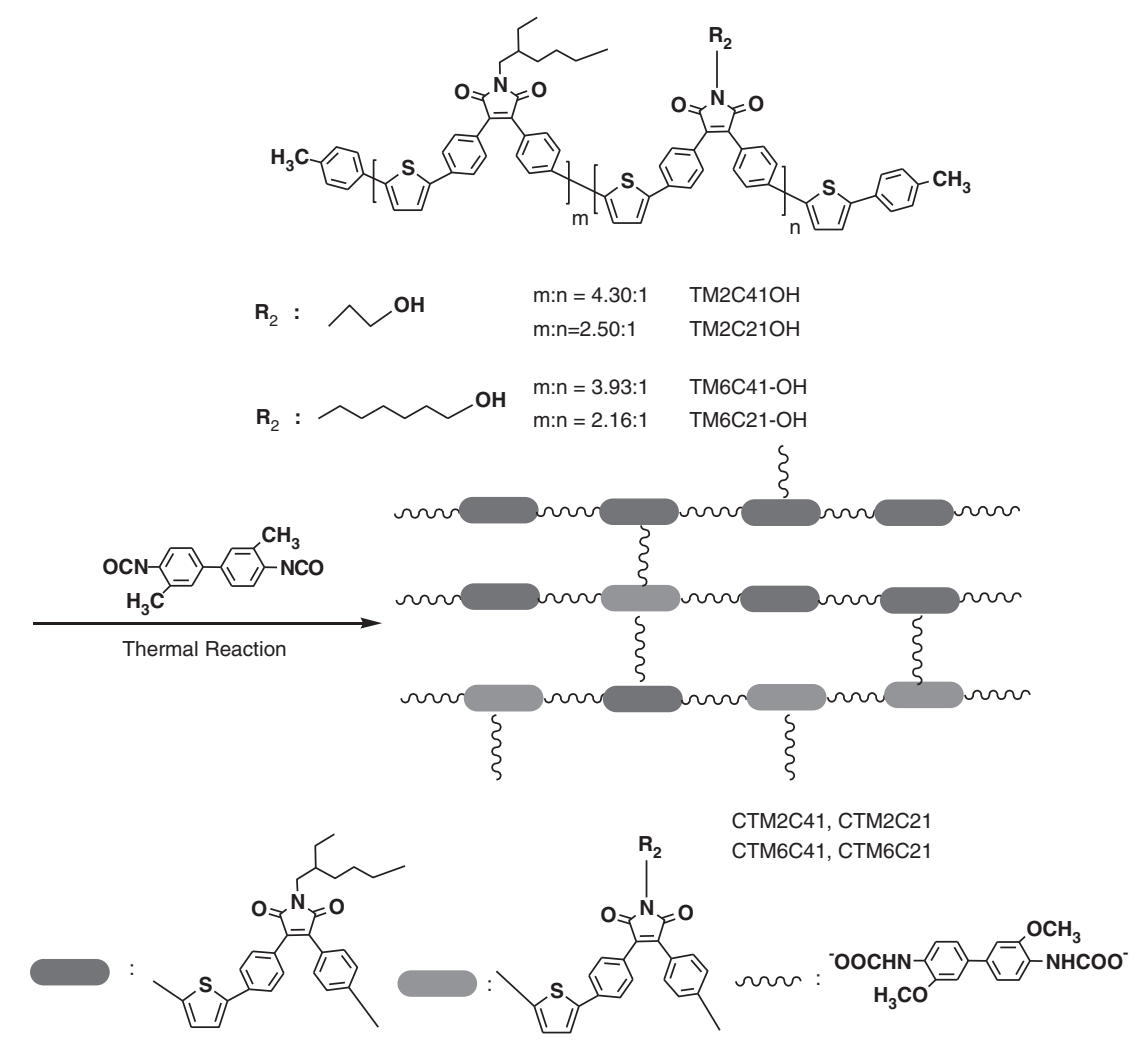

Scheme 2 Synthesis of the interchain-linked maleimide-thiophene copolymers CTM2C41, CTM2C21, CTM6C41 and CTM6C21. A full color version of this figure is available at Polymer Journal online.

Photoluminescence spectra were recorded using a Hitachi F-4500 fluorescence spectrophotometer (Hitachi High-Tech Co., Tokyo, Japan). The redox potentials of the polymers were determined through cyclic voltammetry, using a BAS 100B electrochemical analyzer (Bioanalytical Co., West Lafayette, IN, USA) operated at a scanning rate of $100 \mathrm{mV} \mathrm{s}^{-1}$; the polymer was dissolved in deoxygenated dry dimethylformamide containing $0.1 \mathrm{~m}$ tetra- $n$-butylammonium hexafluorophosphate as the electrolyte; the working electrode was Pt and the reference electrode was saturated non-aqueous $\mathrm{Ag} / \mathrm{AgCl}$; ferrocene was used for potential calibration (all reported potentials are referenced against $\mathrm{Ag} /$ $\mathrm{Ag}^{+}$); and for determining reversibility criteria. The morphologies of the polymer solid films were observed using a Digital Instruments Dimension 3100 Series scanning probe microscope (Veeco Instruments, Plainview, NY, USA).

\section{PSC device fabrication and characterization}

The PSCs had the following structure: indium tin oxide-coated glass/holetransporting material/polymer:PCBM $(90-100 \mathrm{~nm}) / \mathrm{LiF}(0.5 \mathrm{~nm}) / \mathrm{Al}(100 \mathrm{~nm})$. The indium tin oxide-coated glass, having a sheet resistance of $20 \Omega \mathrm{sq}^{-1}$, was purchased from Applied Film Corporation (AF Co., Alzenau, Germany). The PSC fabrication was based on an interpenetrating network of the conjugated polymer and the fullerene derivative PCBM, which was purchased from American Dye Source (ADS Co., Baie Durfe, Quebec, Canada) and used as received. Solutions $\left(30 \mathrm{mg} \mathrm{ml}^{-1}\right)$ of the conjugated polymer and PCBM were prepared at different weight ratios in cyclohexanone (CHO). The PSCs were prepared as follows: glass substrates with patterned indium tin oxide electrodes were washed well and then cleaned through $\mathrm{O}_{2}$ plasma treatment. A thin film of the hole-transporting material-poly(3,4-ethylenedioxythiophene) doped with polystyrenesulfonate (PEDOT:PSS, AI4083; Heraeus Clevios Co., Hanau, Germany) - was deposited on the indium tin oxide layer of the glass substrate using a spin-casting method. The conjugated polymer/ PCBM composite film was spin-coated (1500 r.p.m.) from the CHO solution $\left(30 \mathrm{mg} \mathrm{ml}^{-1}\right.$ ) onto the hole-transporting material layer and then dried at $80^{\circ} \mathrm{C}$ for $1 \mathrm{~h}$ in a glove box. The LiF/Al-based cathode was thermally deposited, in a high-vacuum chamber, onto the photoactive thin film based on the conjugated polymer/PCBM blend. The active area of the PSC was $0.04 \mathrm{~cm}^{2}$. After electrode deposition, the PSC was encapsulated. The cathode deposition rate was determined using a quartz thickness monitor (STM-100/MF; Sycon Instruments, East Syracuse, NY, USA). The thickness of the thin film was determined using a surface texture analysis system (3030ST; Dektak, Veeco Instruments). The PV properties of the PSCs were measured using a programmable electrometer with current and voltage sources (Keithley 2400; Keithley Instruments, Inc., Cleveland, OH, USA) under the illumination of solar light $\left(100 \mathrm{~mW} \mathrm{~cm}^{-2}\right.$ ) from an AM1.5 solar simulator (NewPort Oriel 96000; Newport Corporation Taiwan, Taipei, Taiwan).

\section{RESULTS AND DISCUSSION}

Characterization of the chemical structure and thermal properties of the interchain-linked copolymers

Figure la presents the ${ }^{1} \mathrm{H}$-NMR spectrum of the 6-hydroxyhexylfunctionalized maleimide-thiophene copolymer TM6C21-OH. The signals for protons $\mathrm{g}$ and $(\mathrm{h}+\mathrm{i})$ appear at $\delta 3.5-3.6$ and 3.63.7 p.p.m., respectively, with relative integrals of 5.19 and 4.81, respectively, suggesting that the molar percentage of the 6-hydroxyhexyl-functionalized maleimide-thiophene units was $31.6 \mathrm{~mol} \%$. Accordingly, the molar percentage of 6-hydroxyhexyl-functionalized maleimide-thiophene units in TM6C41-OH was $19.7 \mathrm{~mol} \%$. In addition, the molar percentages of the 2-hydroxyethyl-functionalized maleimide-thiophene units in TM2C41-OH and TM2C21-OH were $18.9 \%$ and $28.6 \%$, respectively. ${ }^{50}$ The chemical shifts and relative intensities of the signals were in agreement with the proposed structures for these conjugated polymers. Figure $1 \mathrm{~b}$ displays the ${ }^{1} \mathrm{H}$ NMR spectrum of the interchain-linked maleimide-thiophene copolymer CTM6C21. Relative to the corresponding signal for TM6C21- 

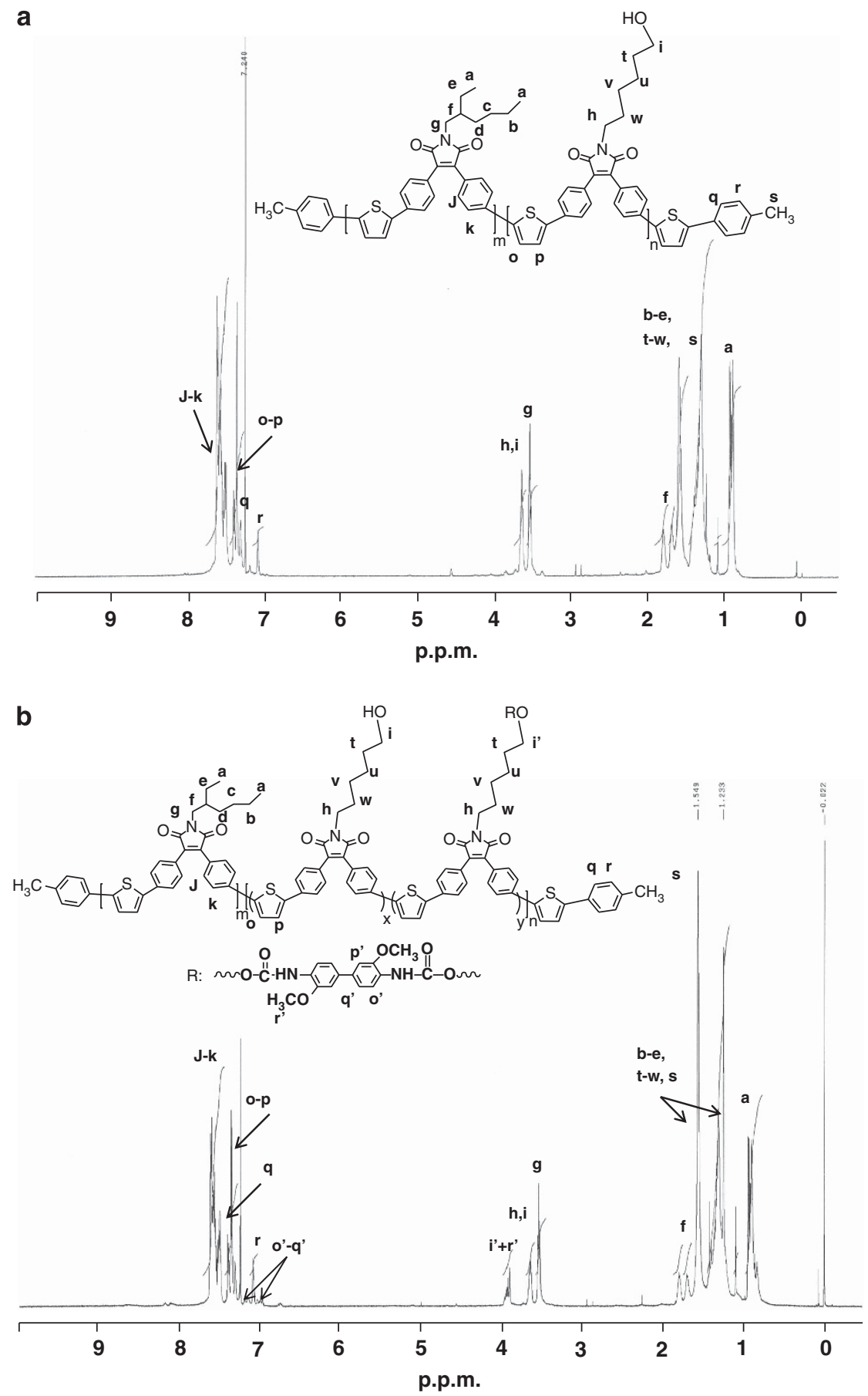

Figure 1 Proton nuclear magnetic resonance $\left({ }^{1} \mathrm{H}-\mathrm{NMR}\right)$ spectra of (a) TM6C21-OH and (b) CTM6C21.

$\mathrm{OH}$, the signal of proton i shifted to lower field after the $\mathrm{OH}$ groups had been reacted with DMBPI, appearing at $\delta 3.88-4.00$ p.p.m. (proton $\mathrm{i}^{\prime}$ ). The signal of protons $\left(\mathrm{i}^{\prime}+\mathrm{r}^{\prime}\right)$ appeared at $\delta 3.88-$ 4.00 p.p.m. for CTM6C21 with a relative integral of 2.43. Notably, the bridge linking of the $\mathrm{OH}$ groups was incomplete: a signal for protons $\mathrm{i}$ of the interchain-linked copolymer CTM6C21 remained at $\delta 3.6-$ 3.7 p.p.m., albeit with diminished absorption intensity. The relative absorption intensity of proton $\mathrm{i}^{\prime}$ indicates that $36.0 \mathrm{~mol} \%$ of the $\mathrm{OH}$ groups had reacted with DMBPI. In addition, the ${ }^{1} \mathrm{H}-\mathrm{NMR}$ spectrum of CTM6C41 indicated that $41.5 \mathrm{~mol} \%$ of the $\mathrm{OH}$ groups had reacted with DMBPI. To prevent gelation of the copolymer, the degree of bridge-linked $\mathrm{OH}$ groups was controlled through the addition of an appropriate amount of DMBPI during the reaction procedure. The lightly interchain-linked copolymers exhibited good solubilities in organic solvents. The ${ }^{1} \mathrm{H}-\mathrm{NMR}$ spectrum of the interchain-linked maleimide-thiophene copolymer CTM2C21 featured signals for protons $(\mathrm{h}+\mathrm{i})$ and $\left(\mathrm{i}^{\prime}+\mathrm{r}^{\prime}\right)$ in the range $\delta 3.8-4.0$ p.p.m. (Figure 2). The signals for protons $\left(i^{\prime}+r^{\prime}\right)$ were overlapped with that of the protons $(h+i)$. Therefore, we could not calculate the degree of bridge linking through DMBPI for CTM2C21. We observed the same behavior for 


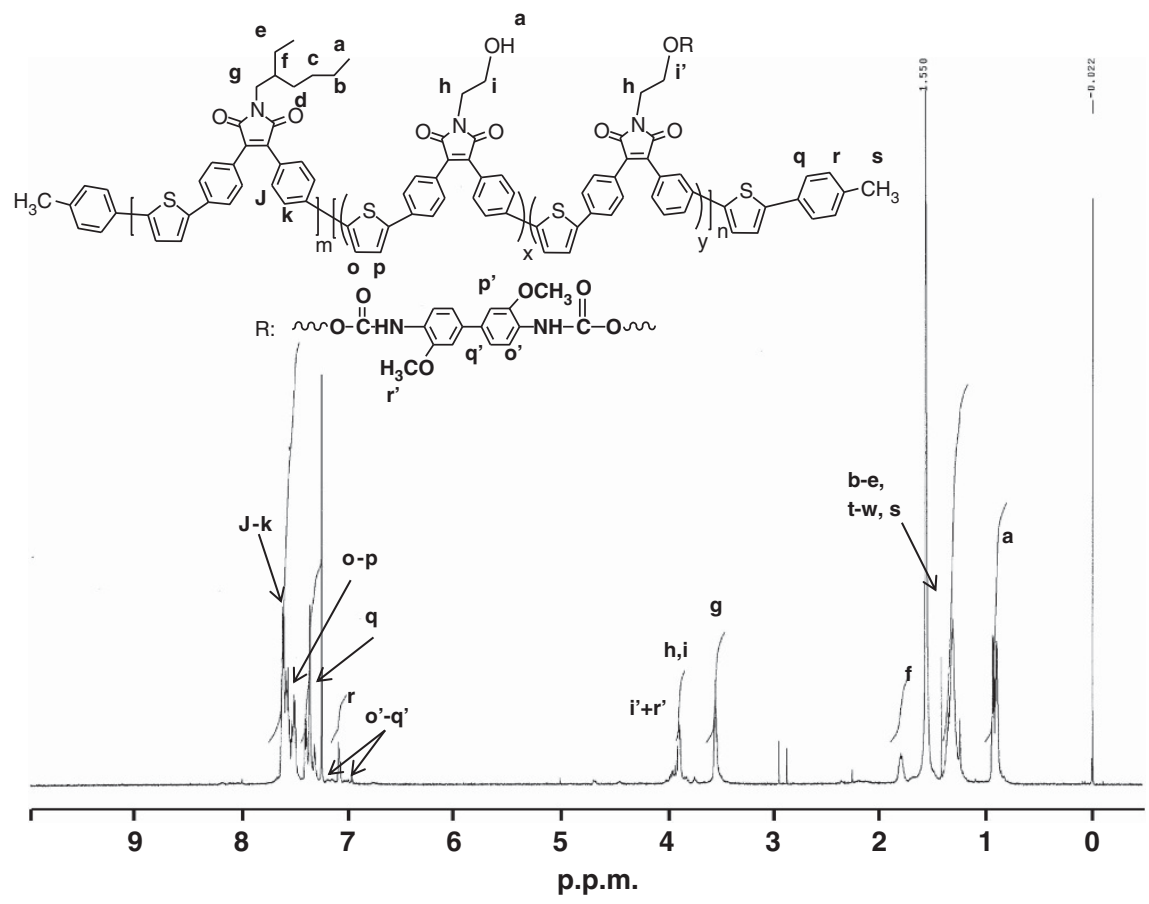

Figure 2 Proton nuclear magnetic resonance $\left({ }^{1} \mathrm{H}-\mathrm{NMR}\right)$ spectrum of the interchain-linked maleimide-thiophene copolymer CTM2C21.

Table 1 Molecular weights and thermal properties of maleimide-thiophene copolymers

\begin{tabular}{|c|c|c|c|c|c|c|c|}
\hline Copolymer & $\mathrm{M}_{n}\left(\mathrm{~kg} \mathrm{~mol}^{-1}\right)$ & $\mathrm{M}_{w}\left(\mathrm{~kg} \mathrm{~mol}^{-1}\right)$ & $P D /\left(\mathrm{M}_{n}\left(\mathrm{M}_{w}\right)\right.$ & $\mathrm{T}_{d}\left({ }^{\circ} C\right)^{\mathrm{a}}$ & $\mathrm{T}_{g}\left({ }^{\circ} \mathrm{C}\right)$ & $\lambda_{\max }^{a b s}(n m)^{\mathrm{b}}$ & $\lambda_{\max }^{a b s}(n m)^{c}$ \\
\hline TM2C21-OH & 3.60 & 6.01 & 1.67 & 287 & 90 & 302,446 & 310,458 \\
\hline TM6C21-OH & 2.15 & 3.87 & 1.82 & 237 & 56 & 298,442 & 306,454 \\
\hline СтM2C41 & 5.29 & 8.41 & 1.59 & 313 & 105 & 330,446 & 332,458 \\
\hline СТM2C21 & 5.94 & 8.26 & 1.39 & 350 & 113 & 322,448 & 320,458 \\
\hline
\end{tabular}

Abbreviations: $\mathrm{CHO}$, cyclohexanone; $M_{\mathrm{n}}$, mass averages of the number; $M_{\mathrm{w}}$, mass averages of the weight; PDI, polydispersity index; $T_{\mathrm{d}}$, thermal degradation; $T_{\mathrm{g}}$, glass transition.

aDegradation temperature at $5 \%$ weight loss.

bMeasured from dilute $\mathrm{CHO}$ solution.

cMeasured from solid film.

dPolymers crosslinked in solution at $80^{\circ} \mathrm{C}$ for $6 \mathrm{~h}$.

CTM2C41. Nevertheless, we could confirm that interchain linking through DMBPI had occurred for CTM2C41 and CTM2C21.

The number- and weight-average molecular weights of the 2hydroxyethyl- and 6-hydroxyhexyl-presenting maleimide-thiophene copolymers TM2C41-OH, TM2C21-OH, TM6C41-OH and TM6C21-OH were ca. $1.92-5.94$ and $3.87-8.41 \mathrm{~kg} \mathrm{~mol}^{-1}$, respectively (Table 1). Moreover, gel permeation chromatography analysis indicated that the number- and weight-average molecular weights of the interchain-linked copolymers were greater than those of the 2-hydroxyethyl- and 6-hydroxyhexyl-presenting copolymers, suggesting that the $\mathrm{OH}$-containing side-chain copolymers had reacted with DMBPI to form interchain-linked polymers. We attribute the higher average molecular weights for the interchain-linked copolymers to the thermal reaction of DMBPI with the $\mathrm{OH}$-containing side-chain copolymers.

The operational stability of a PSC device is directly related to the thermal stability of its conjugated polymers. Thus, high glass transition
$\left(T_{\mathrm{g}}\right)$ and thermal degradation $\left(T_{\mathrm{d}}\right)$ temperatures are desirable if a conjugated polymer is to be applied in PSCs. Supplementary Figure S1 displays DSC thermograms of the $\mathrm{OH}$-containing side-chain copolymers and interchain-linked copolymers. The values of $T_{\mathrm{g}}$ of the $\mathrm{OH}-$ presenting copolymers TM2C41-OH, TM2C21-OH, TM6C41-OH and TM6C21-OH were $86,90,53$ and $56^{\circ} \mathrm{C}$, respectively (Table 1); notably, the values of $T_{\mathrm{g}}$ for the 2-hydroxyethyl-presenting copolymers (TM2C41-OH, TM2C21-OH) were higher than those of the 6hydroxyhexyl-presenting copolymers (TM6C41-OH, TM6C21-OH), presumably because of the lengths of their ethyl and hexyl side chains. Moreover, the values of $T_{\mathrm{g}}$ of the interchain-linked copolymers CTM2C41, CM2C21, CTM6C41 and CTM6C21 were 105, 113, 94 and $66^{\circ} \mathrm{C}$, respectively. Thus, the interchain-linked copolymers possessed higher values of $T_{\mathrm{g}}$ than did the corresponding $\mathrm{OH}-$ presenting copolymers, presumably because of greater average molecular weights and decreased polymer chain mobility. After interchain linking through DMBPI, the enhancement in the values of $T_{\mathrm{g}}$ was 
more pronounced for the copolymers CTM6C41 and CTM6C21 than for the copolymers CTM2C41 and CM2C21, possibly because of the greater degree of bridge linking of the former pair. The 5\% weight loss temperatures $\left(T_{\mathrm{d}}\right)$ of the OH-presenting copolymers TM2C41-OH, TM2C21-OH, TM6C41-OH and TM6C21-OH were 303, 287, 298 and $237^{\circ} \mathrm{C}$, respectively (Table 1 ). Thus, the value of $T_{\mathrm{d}}$ decreased upon increasing the content of side-chain units, presumably because of the presence of $\mathrm{OH}$-containing alkyl side chains. Moreover, the 2hydroxyethyl-presenting copolymers provided higher values of $T_{\mathrm{d}}$ than did the 6-hydroxyhexyl-presenting copolymers, presumably because their shorter alkyl side chains led to the greater thermal stability. In addition, the values of $T_{\mathrm{d}}$ of the interchain-linked copolymers CTM2C41, CM2C21, CTM6C41 and CTM6C21 were 313, 350, 305 and $334^{\circ} \mathrm{C}$, respectively; these values are higher than those of the corresponding side-chain copolymers because of the effect of bridge linking through the DMBPI units.

The copolymers TM2C41-OH, TM2C21-OH, TM6C41-OH and TM6C21-OH had good solubilities in most organic solvents, including $\mathrm{CHO}$, xylene, toluene, THF, $\mathrm{CH}_{2} \mathrm{Cl}_{2}, \mathrm{CHCl}_{3}$ and chlorobenzene (Table 2). In contrast, the interchain-linked copolymers CTM2C41, CTM2C21, CTM6C41 and CTM6C21 had low solubilities in most organic solvents, with the exception of $\mathrm{CHO}$. This behavior is consistent with polar copolymers being more soluble in more polar solvents (for example, $\mathrm{CHO}$ ).

\section{Optical properties of the maleimide-thiophene copolymers}

Figure 3 presents normalized UV-Vis absorption spectra of the $\mathrm{OH}-$ containing side-chain copolymers and interchain-linked copolymers in $\mathrm{CHO}$ solution (concentration: $1 \mathrm{mg} \mathrm{ml}^{-1}$ ) and as solid films (thickness: 90-100 nm). In Figure 3a, the 2-hydroxyethyl- and 6hydroxyhexyl-functionalized copolymers (TM2C41-OH, TM2C21$\mathrm{OH}, \mathrm{TM} 6 \mathrm{C} 41-\mathrm{OH}$ and $\mathrm{TM} 6 \mathrm{C} 21-\mathrm{OH})$ in $\mathrm{CHO}$ solution exhibited their maximum absorption bands centered at approximately $448 \mathrm{~nm}$, with a corresponding additional absorption peak at $325 \mathrm{~nm}$. We attribute the major absorption peak to the $\pi-\pi^{*}$ electronic transition of the conjugated polymer backbone. Slight red-shifting of the absorption peaks occurred for the 2-hydroxyethyl-functionalized copolymers TM2C41-OH and TM2C21-OH relative to those of 6hydroxyhexyl-functionalized copolymers TM6C41-OH and TM6C21$\mathrm{OH}$. We suspect that the presence of the longer alkyl side chains led to greater degrees of twisting of the polymer backbone, thereby shortening the effective conjugation lengths in the copolymers TM6C41$\mathrm{OH}$ and TM6C21-OH relative to those in the copolymers TM2C41$\mathrm{OH}$ and $\mathrm{TM} 2 \mathrm{C} 21-\mathrm{OH}$. In addition, we observed red-shifts and enhanced full-widths at half-maximum of the absorption peaks for the copolymers in the form of solid films, relative to those in solution, presumably because of interactions between and aggregation of the polymer chains in the solid film. Moreover, in the form of solid films, slight red-shifting of the absorption peaks occurred for the 2-hydroxyethyl-functionalized copolymers relative to those of 6-hydroxyhexyl-functionalized copolymers. In addition, Figure 3b presents normalized UV-Vis absorption spectra of the interchainlinked copolymers in $\mathrm{CHO}$ solution and as solid films. Notably, only slight differences existed in the absorption behavior of the interchainlinked copolymers relative to that of the corresponding $\mathrm{OH}$-containing side-chain copolymers. We attribute the enhanced intensity of the absorption peak at $325 \mathrm{~nm}$ for the interchain-linked copolymers, relative to that of the side-chain copolymers, to the absorption of the DMBPI-derived linker between the polymer backbones. In $\mathrm{CHO}$, DMBPI exhibits its maximum absorption wavelength at $300 \mathrm{~nm}$.
Table 2 Solubilities of maleimide-thiophene copolymers in organic solvents

\begin{tabular}{lccccccc}
\hline Polymer $^{\mathrm{a}}$ & $\mathrm{CHO}$ & Xylene & Toluene & $\mathrm{THF}$ & $\mathrm{DCM}$ & $\mathrm{CHCl}_{3}$ & $\mathrm{CB}$ \\
\hline TM2C41-OH & ++ & ++ & ++ & ++ & ++ & ++ & ++ \\
TM2C21-OH & ++ & ++ & ++ & ++ & ++ & ++ & ++ \\
TM6C41-OH & ++ & ++ & ++ & ++ & ++ & ++ & ++ \\
TM6C21-OH & ++ & ++ & ++ & ++ & ++ & ++ & ++ \\
СTM2C41 & ++ & + & + & + & + & + & + \\
СTM2C21 & ++ & + & + & + & + & + & + \\
СTM6C41 & ++ & + & + & + & + & + & + \\
СTM6C21 & ++ & + & + & + & + & + & + \\
РCBM & ++ & ++ & ++ & ++ & ++ & ++ & ++ \\
\hline
\end{tabular}

Abbreviations: $\mathrm{CB}$, chlorobenzene; $\mathrm{CHO}$, cyclohexanone; DCM, dichloromethane; PCBM, [6,6]phenyl- $\mathrm{C}_{61}$-butyric acid methyl ester; THF, tetrahydrofuran; ++ , good solubility; + , poor solubility.

aSolubility measured at a concentration of $20 \mathrm{mg} \mathrm{ml}^{-1}$.
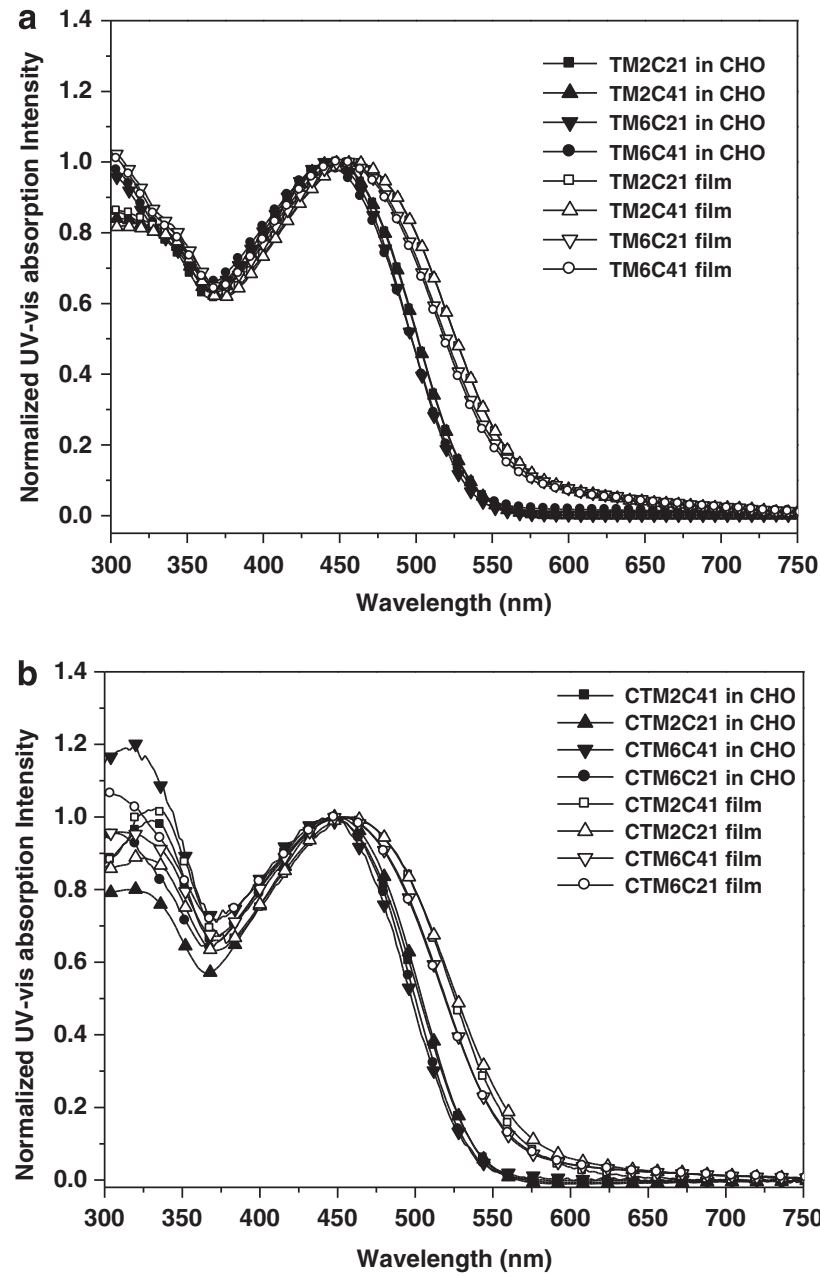

Figure 3 Normalized ultraviolet-visible (UV-Vis) absorption spectra of the $\mathrm{OH}$-functionalized and 3,3'-dimethoxy-4,4'-biphenylene diisocyanate (DMBPI) interchain-linked maleimide-thiophene copolymers in cyclohexanone $(\mathrm{CHO})$ solutions and as solid films (a, TM2C21, TM2C41, TM6C21, TM6C41 samples; b, CTM2C21, CTM2C41, CTM6C21, CTM6C41 samples). 
Electrochemical properties of the maleimide-thiophene copolymers

We employed cyclic voltammetry to investigate the electrochemical behavior of the conjugated polymers and to estimate the energy levels of their highest occupied molecular orbitals (HOMOs) and lowest unoccupied molecular orbitals (LUMOs). We calculated the HOMO energy levels of the copolymers from their onset potentials for oxidation by assuming that the absolute energy level of $\mathrm{Ag} / \mathrm{Ag}^{+}$ was $-4.71 \mathrm{~V}$ below the vacuum level; we calculated LUMO energy levels from the HOMO energy levels and the absorption edge. ${ }^{53}$ Figure 4 displays cyclic voltammetry traces of the $\mathrm{OH}$-containing side-chain copolymers and interchain-linked copolymers; Table 3 summarizes the electrochemical properties of the copolymers. The cyclic voltammograms of TM2C41-OH, TM2C21-OH, TM6C41-OH and $\mathrm{TM} 6 \mathrm{C} 21-\mathrm{OH}$ revealed oxidation onset potentials $\left(E^{\mathrm{ox}}{ }_{\text {onset }}\right)$ at $0.80,0.85,0.83$ and $0.87 \mathrm{~V}$, respectively; that is, the value of $E^{\text {ox }}{ }_{\text {onset }}$ increased upon increasing the content of $\mathrm{OH}$ groups in the copolymers, presumably because they induced an increased degree of twisting of the polymer backbone, out of planarity. ${ }^{55}$ Such twisting of the polymer backbone decreased the effective conjugation length, thereby enhancing the value of $E^{\text {ox }}{ }_{\text {onset }}{ }^{55}$ In addition, the values of $E^{\text {ox }}{ }_{\text {onset }}$ for the 6-hydroxyhexyl-functionalized copolymers were higher than those of the 2-hydroxyethyl-functionalized copolymers. This observation implies that the presence of 6-hydroxyhexyl groups twisted the polymer backbone more significantly than did the
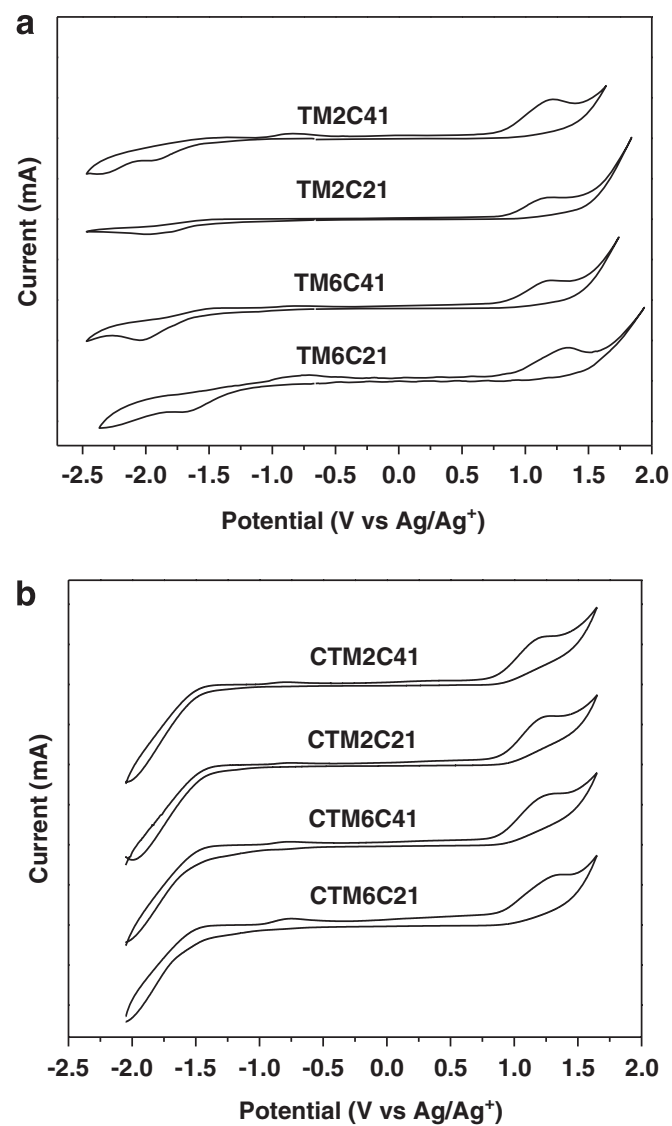

Figure 4 Electrochemical properties of the $\mathrm{OH}$-functionalized and $3,3^{\prime}$ dimethoxy-4,4'-biphenylene diisocyanate (DMBPI) interchain-linked maleimide-thiophene copolymers (a, TM2C21, TM2C41, TM6C21, TM6C41 samples; b, СTM2C21, CTM2C41, CTM6C21, СTM6C41 samples). presence of 2-hydroxyethyl groups. The LUMO energy levels of TM2C41-OH, TM2C21-OH, TM6C41-OH and TM6C21-OH were $-3.21,-3.25,-3.22$ and $-3.25 \mathrm{eV}$, respectively; the HOMO energy levels were $-5.51,-5.56,-5.54$ and $-5.58 \mathrm{eV}$, respectively. Thus, for the OH-containing side-chain copolymers, the LUMO and $\mathrm{HOMO}$ energy levels decreased upon increasing the content of $\mathrm{OH}$ groups. The decrease in the HOMO energy level upon increasing the $\mathrm{OH}$ group content corresponds with the increased value of $E^{\text {ox }}{ }_{\text {onset }}{ }^{55}$ Moreover, the HOMO energy levels of the 6-hydroxyhexylfunctionalized copolymers were lower than those of the 2hydroxyethyl-functionalized copolymers. On the other hand, the optical band gap of each copolymer, determined from the absorption edge, was approximately $2.3 \mathrm{eV}$. Thus, the optical band gap did not vary significantly with respect to the $\mathrm{OH}$ group content. As a result, the LUMO energy levels for the copolymers decreased upon increasing the $\mathrm{OH}$ group content.

Furthermore, the values of $E^{\text {ox }}$ onset for the interchain-linked copolymers were higher than those of the corresponding $\mathrm{OH}$ containing side-chain copolymers. The LUMO energy levels for CTM2C41, CTM2C21, CTM6C41 and CTM6C21 were -3.25, $-3.26,-3.25$ and $-3.28 \mathrm{eV}$, respectively; their HOMO energy levels were $-5.55,-5.57,-5.57$ and $-5.61 \mathrm{eV}$, respectively. Relative to those of the $\mathrm{OH}$-presenting copolymers, the values of $E^{\mathrm{ox}}$ onset were further enhanced after bridging the side chains of the copolymers through DMBPI units. Such interchain linking increased the degree of twisting of the polymer backbone, thereby decreasing the effective conjugation length and, accordingly, increasing the value of $E^{\text {ox }}$ onset ${ }^{55}$ We observed higher values of $E^{\text {ox }}$ onset for CTM6C41 and CTM6C21 relative to those of $\mathrm{TM} 6 \mathrm{C} 41-\mathrm{OH}$ and $\mathrm{TM} 6 \mathrm{C} 21-\mathrm{OH}$, presumably because of the higher degree of bridging through DMBPI units for CTM6C41 and CTM6C21. In addition, the decrease in the HOMO energy level upon increasing the degree of bridge linking correlated with the increase in the value of $E^{\text {ox }}{ }_{\text {onset }}{ }^{55}$ Because the optical band gap did not vary significantly with respect to the degree of bridge linking of the copolymers, the interchain-linked copolymers possessed lower LUMO energy levels relative to those of the corresponding $\mathrm{OH}-$ containing side-chain copolymers.

Optical properties and morphologies of maleimide-thiophene copolymer/PCBM blend films

Supplementary Figure S2 presents normalized UV-Vis absorption spectra of $\mathrm{OH}$-containing side-chain copolymer/PCBM and interchain-linked copolymer/PCBM blend films prepared at various weight ratios. The absorption bands of the conjugated copolymers extended from 360 to $700 \mathrm{~nm}$, whereas that of PCBM ranged from

Table 3 Electrochemical properties of maleimide-thiophene copolymers

\begin{tabular}{lccccc} 
Copolymer & Ex $^{\text {onset }}(\mathrm{V})$ & UV-Vis onset $(\mathrm{nm})$ & HOMO (eV) & LUMO (eV) & $\mathrm{E}_{g}(\mathrm{eV})$ \\
\hline TM2C41-OH & 0.80 & 537.07 & -5.51 & -3.21 & 2.30 \\
TM2C21-OH & 0.85 & 536.78 & -5.56 & -3.25 & 2.31 \\
TM6C41-OH & 0.83 & 534.25 & -5.54 & -3.22 & 2.32 \\
TM6C21-OH & 0.87 & 533.06 & -5.58 & -3.25 & 2.33 \\
CTM2C41 & 0.84 & 537.31 & -5.55 & -3.25 & 2.30 \\
CTM2C21 & 0.86 & 536.78 & -5.57 & -3.26 & 2.31 \\
CTM6C41 & 0.86 & 533.41 & -5.57 & -3.25 & 2.32 \\
CTM6C21 & 0.90 & 532.56 & -5.61 & -3.28 & 2.33
\end{tabular}

Abbreviations: $E_{g}$, energy gap; $E^{0 x}{ }_{\text {onset, }}$ oxidation onset potentials; UV, ultraviolet; Vis, visible; HOMO, highest occupied molecular orbital; LUMO, lowest unoccupied molecular orbital. 
300 to $360 \mathrm{~nm}$. The maximum absorptions of the conjugated copolymers and PCBM appeared at approximately 450 and $325 \mathrm{~nm}$, respectively. Moreover, for the maleimide-thiophene copolymer/ PCBM blend films, the absorption intensity of the conjugated copolymer decreased upon increasing the PCBM content. Notably, the absorption behaviors of the $\mathrm{OH}$-containing side-chain copolymer/ PCBM and interchain-linked copolymer/PCBM blend films were similar.

We used AFM to investigate the compatibility and morphology of the maleimide-thiophene copolymer/PCBM blend films, because the PV properties of PSCs are closely related to the morphology within the photoactive polymer blend. Supplementary Figure S3 displays topographic and phase images of the TM2C41-OH/PCBM $(1: 4(\mathrm{w} / \mathrm{w}))$ and TM2C21-OH/PCBM (1:4 (w/w)) blend films, respectively, after they had been annealed at $80^{\circ} \mathrm{C}$ for $1 \mathrm{~h} .{ }^{50}$ Table 4 summarizes the roughnesses of the composite films. For the TM2C41$\mathrm{OH} / \mathrm{PCBM}$ blend films, the presence of the hydrogen bonds between the $\mathrm{OH}$ groups of $\mathrm{TM} 2 \mathrm{C} 41-\mathrm{OH}$ and the ester group of PCBM enhanced the compatibility of the components. As a result, the PCBM units were mixed uniformly in the TM2C41-OH/PCBM blend films. In Supplementary Figure S3, we do not observe a phase-separated interpenetrating network with sizable PCBM domains for the TM2C41-OH/PCBM blend film incorporating a high PCBM content $(1: 4(w / w))$. In contrast, we observed a phase-separated interpenetrating network with PCBM domains for the TM2C21-OH/PCBM composite film featuring a low PCBM content $(1: 1(\mathrm{w} / \mathrm{w}))$, presumably because the high content of $\mathrm{OH}$ groups of TM2C21-OH led to significant hydrogen bonding among the $\mathrm{OH}$ groups and, therefore, self-aggregation of the conjugated polymer chains. Self-aggregation of the polymer chains led to the high contrast ratios for the PCBM domains and TM2C21-OH matrix in the phase images of the TM2C21-OH/PCBM blend films. In addition, the surface morphologies of the TM2C41-OH/PCBM composite films did not vary significantly upon increasing the PCBM content. Although we observed greater surface roughnesses for blend films incorporating the copolymer featuring the higher $\mathrm{OH}$ group content, the distribution of PCBM domains in the TM2C21-OH/PCBM blend films was

Table 4 PV properties of PSCs incorporating films of maleimidethiophene copolymer/PCBM blends

\begin{tabular}{|c|c|c|c|c|c|c|}
\hline PSC & $\begin{array}{l}\text { Polymer:PCBM } \\
\qquad(w / w)\end{array}$ & $\mathrm{R}(n m)$ & $\mathrm{V}_{O C}(\mathrm{~V})$ & $J_{S C}\left(m A c m^{-2}\right)$ & $F F(\%)$ & $\eta(\%)$ \\
\hline PSC Al-1 & TM2C41-OH:PCBM (1:1) & 0.39 & 0.50 & 0.113 & 34.2 & 0.02 \\
\hline PSC Al-2 & TM2C41-OH:PCBM (1:2) & 0.39 & 0.47 & 0.221 & 36.9 & 0.04 \\
\hline PSC Al-3 & TM2C41-OH:PCBM (1:4) & 0.40 & 0.43 & 0.378 & 33.6 & 0.06 \\
\hline PSC All-1 & TM2C21-OH:PCBM (1:1) & 0.37 & 0.50 & 0.146 & 31.2 & 0.02 \\
\hline PSC All-2 & TM2C21-OH:PCBM (1:2) & 0.42 & 0.46 & 0.260 & 36.8 & 0.04 \\
\hline PSC All-3 & TM2C21-OH:PCBM (1:4) & 0.46 & 0.44 & 0.425 & 34.7 & 0.07 \\
\hline PSC AllI-1 & TM6C41-OH:PCBM (1:1) & 0.39 & 0.68 & 0.020 & 30.6 & 0.01 \\
\hline PSC AIII-2 & TM6C41-OH:PCBM (1:2) & 0.41 & 0.70 & 0.046 & 33.8 & 0.01 \\
\hline PSC AllI-3 & TM6C41-OH:PCBM (1:4) & 0.39 & 0.62 & 0.070 & 36.6 & 0.02 \\
\hline PSC AIV-1 & TM6C21-OH:PCBM (1:1) & 0.42 & 0.68 & 0.032 & 31.1 & 0.01 \\
\hline PSC AIV-2 & TM6C21-OH:PCBM (1:2) & 0.41 & 0.66 & 0.084 & 31.0 & 0.01 \\
\hline PSC AIV-3 & TM6C21-OH:PCBM (1:4) & 0.43 & 0.62 & 0.183 & 29.1 & 0.02 \\
\hline
\end{tabular}

suitable for electron transport in PSCs. Figure 5 displays topographic and phase images of the TM6C41-OH/PCBM and TM6C21-OH/ PCBM blend films, respectively, after they had been annealed at $80^{\circ} \mathrm{C}$ for $1 \mathrm{~h}$. These AFM images indicate that the PCBM units were mixed uniformly in the TM6C41-OH/PCBM blend films, due to the presence of hydrogen bonds among the $\mathrm{OH}$ groups of TM6C41$\mathrm{OH}$ and the ester group of PCBM. Moreover, we also observed good compatibility for the TM6C21-OH/PCBM blend film $(1: 4(\mathrm{w} / \mathrm{w}))$. Self-aggregation of the polymer chains, as a result of the high $\mathrm{OH}$ group content of TM6C21-OH, did not occur in the blend films of TM6C21-OH/PCBM, presumably because of dilution of the long side-chain groups. We did not observe a high contrast ratio for the PCBM domains and polymer matrix in the phase image of the TM6C21-OH/PCBM blend film.

Figures 6 and 7 present phase images of the interchain-linked copolymer (CTM2C41, CTM2C21, CTM6C41 and CTM6C21)/ PCBM blend films. Although the morphologies of the CTM2C41/ PCBM (1:1 and 1:4, w/w) blend films were quite distinct from those of the TM2C41-OH/PCBM blend films, the phase images revealed the uniform distribution of PCBM units in the CTM2C41 matrix, due to the lower content of $\mathrm{OH}$ groups and the lower degree of the interchain linking through DMBPI units. In addition, for the CTM2C21/PCBM composite films we observed phase-separated interpenetrating networks with PCBM domains. The size of the PCBM domains in CTM2C21 was much smaller than that in TM2C21-OH, presumably because the content of $\mathrm{OH}$ groups was lower after forming the bridging links through DMBPI units. As a result, self-aggregation of the conjugated polymer chains was prevented in the blend film. The PCBM and conjugated polymer units in CTM2C21/PCBM blend films had greater compatibility than that in the TM2C21-OH/PCBM blend films. Nevertheless, the phase images of the interchain-linked copolymer (CTM6C41, CTM6C21)/PCBM blend films were similar to those of the CTM2C41/PCBM blend films. The phase images revealed the uniform distributions of PCBM units in the CTM6C41 and CTM6C21 matrices, except in the CTM6C21/ PCBM $(1: 4(w / w))$ blend film, presumably because the higher degree of bridging links through DMBPI units decreased the compatibility between the polymer chains and the PCBM units in the CTM6C21/ PCBM blend film.

\section{PV properties of PSCs based on maleimide-thiophene copolymer/} PCBM blend films

We fabricated PSCs incorporating films of maleimide-thiophene copolymer/PCBM blends prepared from $\mathrm{CHO}$ solutions using an optimized spin-coating procedure. The photoactive layers based on copolymer (TM2C41-OH, TM2C21-OH, TM6C41-OH and TM6C21-OH)/PCBM blends were thermally treated at $80^{\circ} \mathrm{C}$ for $1 \mathrm{~h}$. Figure 8 displays the photocurrent density-voltage plots of the PSCs we fabricated from maleimide-thiophene copolymer/PCBM blend films of various weight ratios. Table 4 summarizes the PV properties of these PSCs, including their open-circuit voltages $\left(V_{\mathrm{OC}}\right)$, short-circuit current densities $\left(J_{\mathrm{SC}}\right)$, fill factors and photo-energy conversion efficiencies $(\eta)$. For the $\mathrm{OH}$-containing side-chain copolymer/PCBM-based PSCs (PSC AI-1-PSC AIV-3), the values of $J_{\text {SC }}$ and $\eta$ increased upon increasing the PCBM content, whereas the values of $V_{\mathrm{OC}}$ followed the opposite trend. Higher concentrations of PCBM favored the formation of phase-separated interpenetrating networks with sizable domains in the photoactive layer, ${ }^{56,57}$ in turn favoring effective charge separation, ${ }^{58,59}$ as a result, we observed higher values of $J_{\mathrm{SC}}$ and $\eta$. Conversely, the values of $V_{\mathrm{OC}}$ decreased slightly upon increasing the PCBM content. Although the value of 

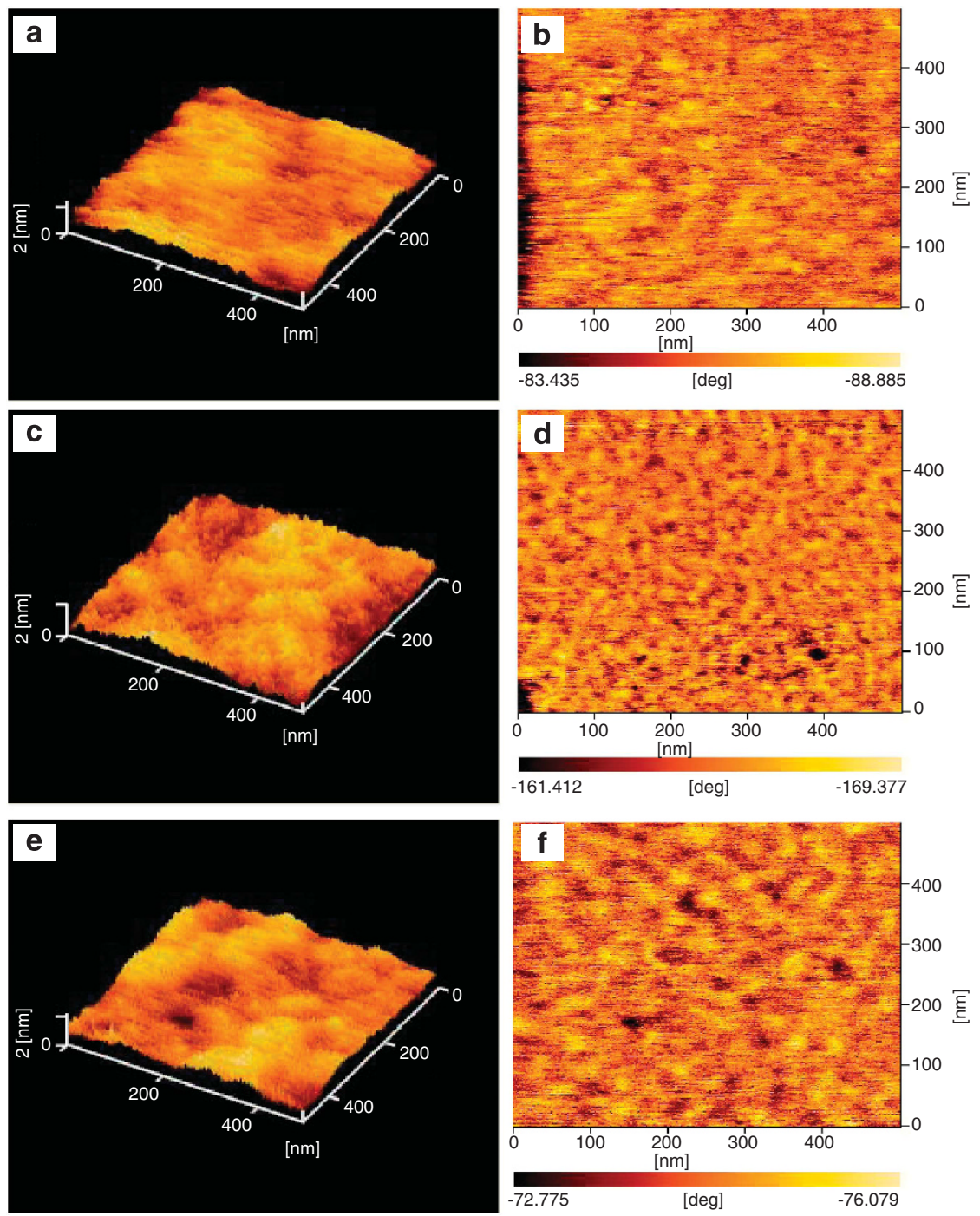

Figure 5 Atomic force microscopy (AFM) images of films of the TM6C41-OH/[6,6]-phenyl- $\mathrm{C}_{61}$-butyric acid methyl ester (PCBM) and TM6C21-OH/PCBM blends. (a, c, e) Topographic images; (b, d, f) phase images. TM6C41-OH/PCBM ratio $\left(\mathrm{ww}^{-1}\right)$ : (a, b) =1:1; (c, d) 1:4; TM6C21-OH/PCBM ratio (w/w): $(\mathbf{e}, \mathbf{f})=1: 4$. Polymer films had been dried at $80^{\circ} \mathrm{C}$ for $1.0 \mathrm{~h}$.

$V_{\mathrm{OC}}$ is determined mainly by the difference between the LUMO energy level of the electron acceptor (in this case, PCBM) and the HOMO energy level of the electron-donor (the conjugated polymer), it is also affected by the PCBM content because charge transfer occurs between the polymer and PCBM. Consequently, the values of $V_{\mathrm{OC}}$ decreased upon increasing the PCBM content. ${ }^{60}$ In addition, the values of $J_{\mathrm{SC}}$ and $\eta$ for the TM2C21-OH/PCBM-based PSCs (PSC AII-1-PSC AII-3) were higher than those of the TM2C41-OH/ PCBM-based PSCs (PSC AI-1-PSC AI-3), presumably because of the presence of more-suitable charge transfer channels in the TM2C21-OH/PCBM blend films. Nevertheless, the values of VOC of the TM2C21-OH/PCBM-based PSCs were not higher than those of the TM2C41-OH/PCBM-based PSCs, even through the HOMO energy level of TM2C21-OH was lower than that of TM2C41-OH. Nevertheless, the influence of the content of $\mathrm{OH}$ groups on the $\mathrm{PV}$ properties of the PSCs based on the TM6C41-OH/PCBM and TM6C21-OH/PCBM blends (PSC AIII-1-PSC AIII-3 and PSC AIV1-PSC AIV-3) was the same as those of the PSCs based on TM2C21$\mathrm{OH} / \mathrm{PCBM}$ and TM2C41-OH/PCBM. The values of $V_{\mathrm{OC}}$ of the 6-hydroxyhexyl-presenting copolymer (TM6C41-OH and TM6C21$\mathrm{OH}) / \mathrm{PCBM}$-based PSCs were slightly higher than those of the 2-hydroxyethyl-presenting copolymer (TM2C41-OH and TM2C21$\mathrm{OH}) / \mathrm{PCBM}$-based PSCs, presumably because the HOMO energy levels of TM6C41-OH and TM6C21-OH were lower than those of TM2C41-OH and TM2C21-OH, respectively. Conversely, the values of $J_{\mathrm{SC}}$ and $\eta$ of the PSCs based on TM6C41-OH/PCBM and TM6C21$\mathrm{OH} / \mathrm{PCBM}$ were lower than those of the PSCs based on TM2C41$\mathrm{OH} / \mathrm{PCBM}$ and TM2C21-OH/PCBM, presumably because of the differences in the lengths of the alkyl side chains of the copolymers. Longer alkyl side chains led to lower concentrations of the conjugated polymer backbones in the polymer matrices. As a result, we observed a lower hole-transporting capacity for the photoactive layer based on the 6-hydroxyhexyl-presenting copolymer/PCBM blend.

Figure 9 displays the photocurrent density-voltage plots of the PSCs (PSC BI-1-PSC BIV-3) that we fabricated from interchainlinked maleimide-thiophene copolymer (CTM2C41, CTM2C21, CTM6C41 and CTM6C21)/PCBM blend films of various weight ratios); Table 5 summarizes the PV properties of these PSCs. The PV 

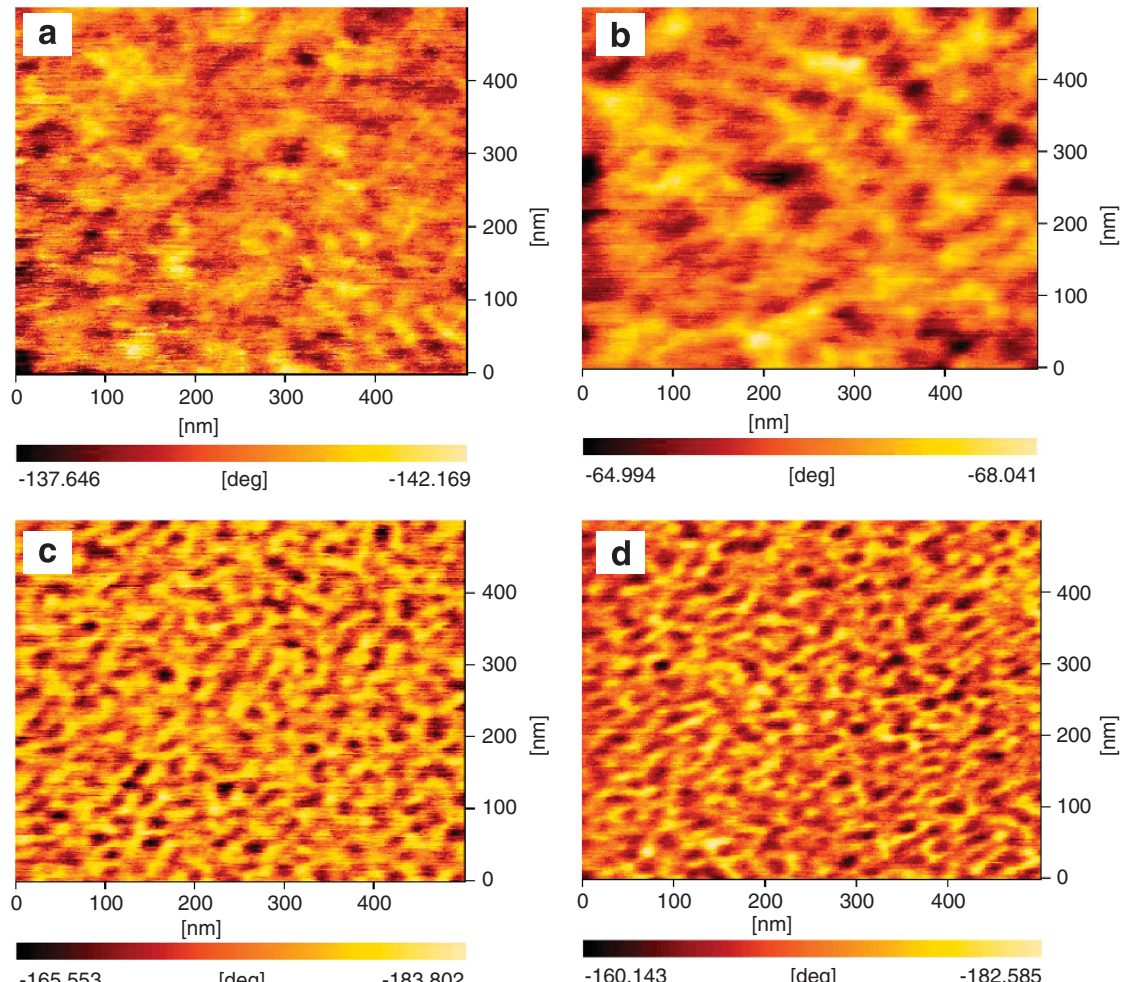

Figure 6 Atomic force microscopy (AFM) images of films of the CTM2C41/[6,6]-phenyl- $\mathrm{C}_{61}$-butyric acid methyl ester (PCBM) and CTM2C21/PCBM blends. CTM2C41/PCBM ratio (w/w): (a)=1:2; (b) 1:4; CTM2C21/PCBM ratio (w/w): (c)=1:2; (d) $1: 4$. Polymer films had been dried at $80^{\circ} \mathrm{C}$ for $1.0 \mathrm{~h}$.
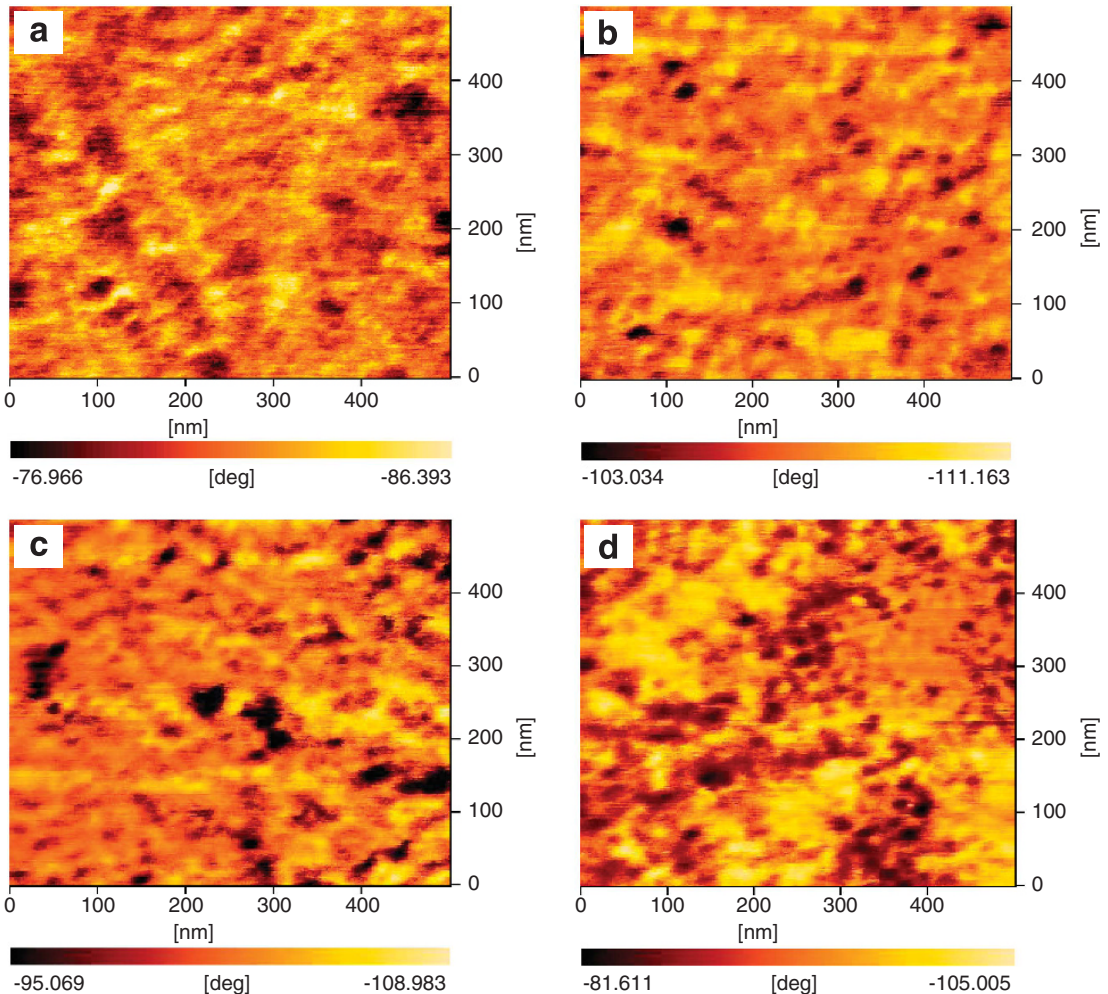

Figure 7 Atomic force microscopy (AFM) images of films of the CTM6C41/[6,6]-phenyl- $\mathrm{C}_{61}$-butyric acid methyl ester (PCBM) and CTM6C21/PCBM blends. CTM6C41/PCBM ratio (w/w): (a)=1:2; (b) 1:4; CTM6C21/PCBM ratio (w/w): (c)=1:2; (d) 1:4. Polymer films had been dried at $80^{\circ} \mathrm{C}$ for $1.0 \mathrm{~h}$. 

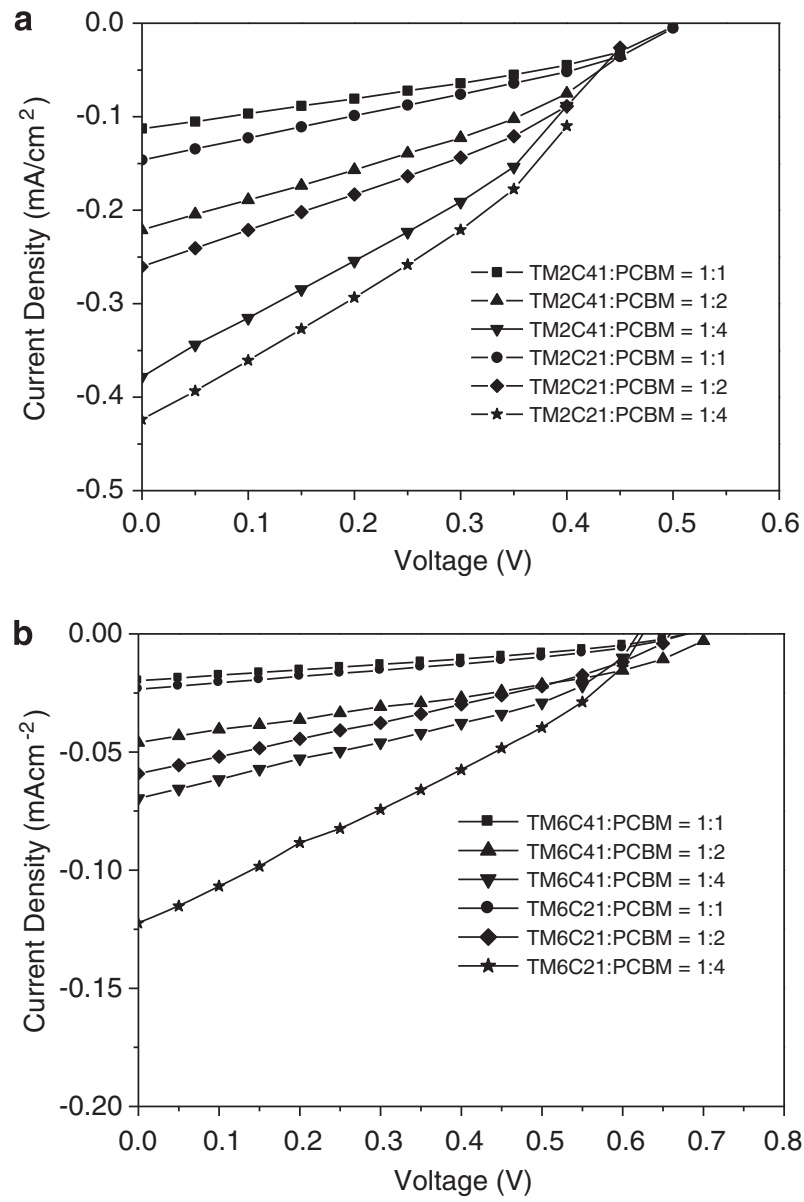

Figure 8 Current density-voltage plots of polymer solar cells (PSCs) fabricated from films of the $\mathrm{OH}$-functionalized maleimide-thiophene copolymer//[6,6]-phenyl- $\mathrm{C}_{61}$-butyric acid methyl ester (PCBM) blends. Polymer films had been dried at $80^{\circ} \mathrm{C}$ for $1.0 \mathrm{~h}$ (a, TM2C21 and TM2C41 based PSCs; b, TM6C21 and TM6C41 based PSCs).

performances of the PSCs based on the interchain-linked copolymers (PSC BI-1-PSC BIV-3) were superior to those of the PSCs based on the 2-hydroxyethyl- and 6-hydroxyhexyl-functionalized copolymers (PSC AI-1-PSC AIV-3). One possible reason for this behavior is that the content of $\mathrm{OH}$ groups was lower in the interchain-linked copolymers. The $\mathrm{OH}$ groups on the surface of the photoactive layer would have reacted with the $\mathrm{Al}$ to form metal oxides, which would resist electron injection from the photoactive layer to the cathode, thereby resulting in low photocurrent densities for these PSC. ${ }^{61}$ Moreover, the interchain-linked copolymers with higher average molecular weights formed higher-quality thin films than did the corresponding $\mathrm{OH}$-presenting maleimide-thiophene copolymers. A poor-quality polymer film results in a low charge transporting capacity in the photoactive layer. In addition, conjugated polymers with high hole mobilities can be obtained from interchain-linked conjugated polymers featuring a suitable content of conjugated bridges. ${ }^{62}$ Accordingly, we observed higher values of $J_{S C}$ for the interchain-linked copolymer/PCBM-based PSCs, even though the films of the interchain-linked copolymer/PCBM blends (CTM6C21/ PCBM blends) possessed poorer phase-separated morphologies than
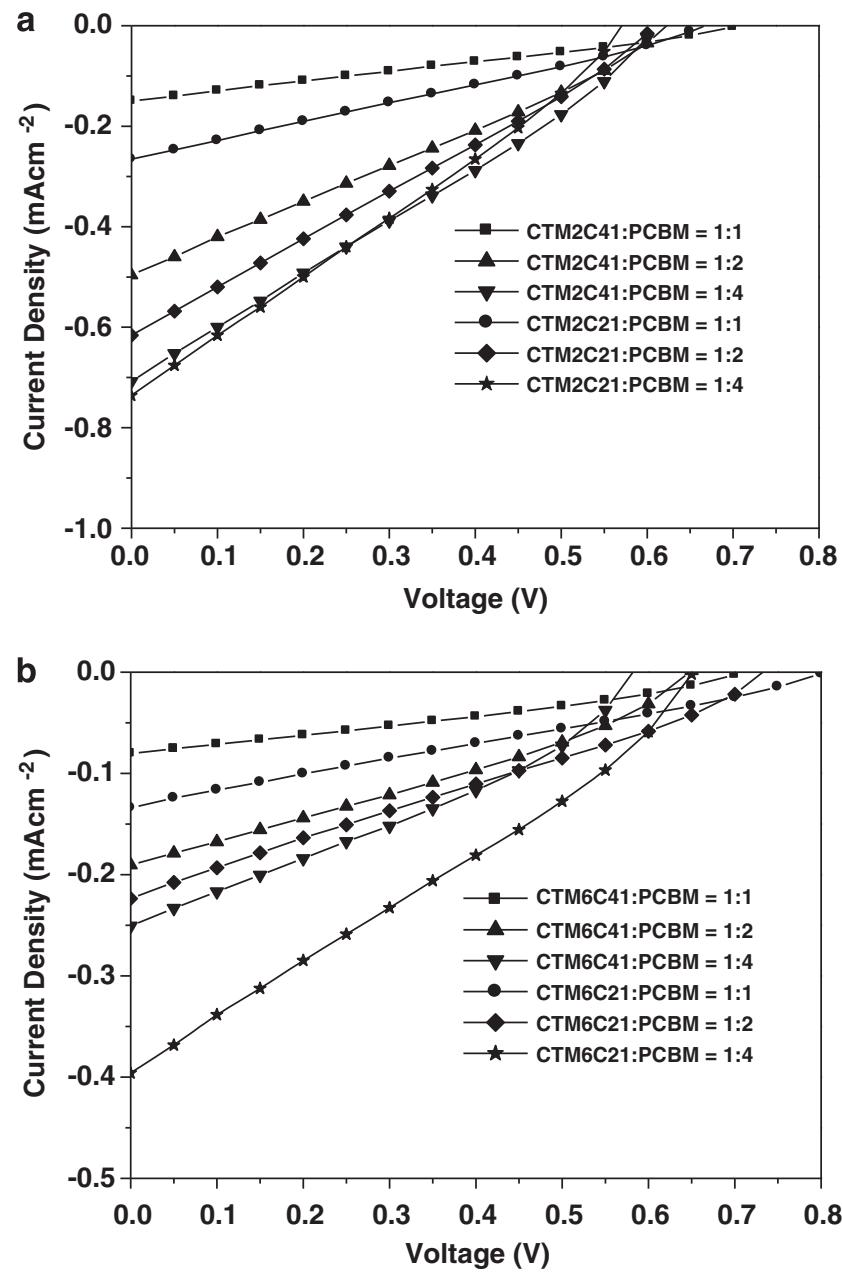

Figure 9 Current density-voltage plots of polymer solar cells (PSCs) fabricated from the films of 3,3'-dimethoxy-4,4'-biphenylene diisocyanate (DMBPI) interchain-linked maleimide-thiophene copolymer//[6,6]-phenyl$\mathrm{C}_{61}$-butyric acid methyl ester (PCBM) blends. Polymer films had been dried at $80{ }^{\circ} \mathrm{C}$ for $1.0 \mathrm{~h}$ (a, CTM2C21 and CTM2C41 based PSCs; b, CTM6C21 and CTM6C41 based PSCs).

did those of the corresponding OH-functionalized copolymer/PCBM blends. In addition, we attribute the higher values of $V_{\mathrm{OC}}$ of the PSCs based on the interchain-linked copolymer (CTM2C41, CTM2C21, CTM6C41 and CTM6C21)/PCBM blends to the lower HOMO energy levels of the interchain-linked copolymers. Notably, however, the low HOMO energy levels of the interchain-linked copolymers would inhibit hole injection from the photoactive layer to the holetransporting material layer. Therefore, we observed higher series resistivities and lower fill factors for the PSCs incorporating the interchain-linked copolymer/PCBM blends than those for the PSCs based on the corresponding $\mathrm{OH}$-functionalized copolymer/PCBM blends. Nevertheless, the values of $\eta$ of the PSCs based on the interchain-linked copolymers were higher than those of the PSCs based on the $\mathrm{OH}$-functionalized copolymers. On the other hand, the PV performances of our PSCs based on the maleimide-thiophene copolymers were lower than those of PSCs based on poly(3hexylthiophene), presumably because of the low average molecular weight and narrow absorption band of the maleimide-thiophene copolymers. The low average molecular weight resulted in poorquality polymer films, and thereby, the low charge transporting 
Table 5 PV properties of PSCs incorporating films of interchainlinked maleimide-thiophene copolymer/PCBM blends

\begin{tabular}{lllllll}
\hline PSC & Polymer:PCBM (w/w) & $\mathrm{R}(n m)$ & $\mathrm{V}_{\text {OC }}(\mathrm{V})$ & $\mathrm{J}_{S C}\left(\mathrm{mAcm}{ }^{-2}\right)$ & $F F(\%)$ & $\eta(\%)$ \\
\hline PSC BI-1 & CTM2C41:PCBM (1:1) & 0.49 & 0.67 & 0.267 & 27.5 & 0.05 \\
PSC BI-2 & CTM2C41:PCBM (1:2) & 0.45 & 0.61 & 0.616 & 26.8 & 0.10 \\
PSC BI-3 & CTM2C41:PCBM (1:4) & 0.44 & 0.57 & 0.737 & 28.4 & 0.12 \\
& & & & & & \\
PSC BII-1 & CTM2C21:PCBM (1:1) & 0.43 & 0.70 & 0.150 & 27.3 & 0.03 \\
PSC BII-2 & CTM2C21:PCBM (1:2) & 0.41 & 0.62 & 0.497 & 28.6 & 0.10 \\
PSC BII-3 & CTM2C21:PCBM (1:4) & 0.37 & 0.60 & 0.706 & 27.9 & 0.12 \\
& & & & & & \\
PSC BIII-1 & CTM6C41:PCBM (1:1) & 0.36 & 0.70 & 0.080 & 31.2 & 0.02 \\
PSC BIII-2 & CTM6C41:PCBM (1:2) & 0.33 & 0.65 & 0.190 & 31.2 & 0.04 \\
PSC BIII-3 & CTM6C41:PCBM (1:4) & 0.34 & 0.58 & 0.250 & 31.4 & 0.05 \\
& & & & & & \\
PSC BIV-1 & CTM6C21:PCBM (1:1) & 0.33 & 0.80 & 0.134 & 26.5 & 0.03 \\
PSC BIV-2 & CTM6C21:PCBM (1:2) & 0.36 & 0.73 & 0.224 & 26.3 & 0.05 \\
PSC BIV-3 & CTM6C21:PCBM (1:4) & 0.31 & 0.65 & 0.396 & 28.1 & 0.07 \\
\hline
\end{tabular}

Abbreviations: $\eta$, photo-energy conversion efficiencies; FF, fill factor; J J , short-circuit current densities; PCBM, [6,6]-phenyl- $\mathrm{C}_{61}$-butyric acid methyl ester; PSC, polymer solar cells; PV, photovoltaic; $V_{0 c}$, open-circuit voltage.

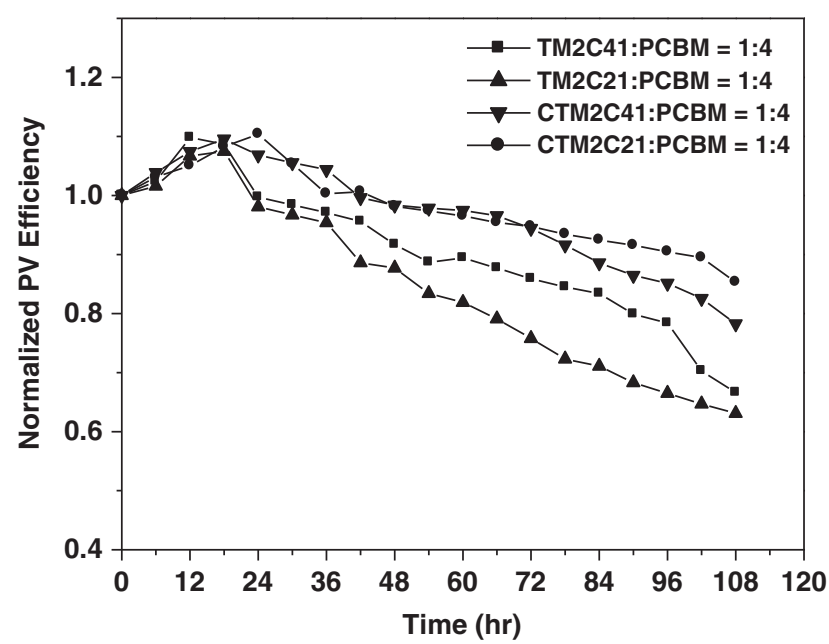

Figure 10 Temporal plots of photovoltaic (PV) efficiencies of polymer solar cells (PSCs) fabricated from films of TM2C41//[6,6]-phenyl- $\mathrm{C}_{61}$-butyric acid methyl ester (PCBM), TM2C21/PCBM, CTM2C41/PCBM and CTM2C21/ PCBM blends. Polymer films had been dried at $80^{\circ} \mathrm{C}$ for $1.0 \mathrm{~h}$.

capacity in the photoactive layer. Nevertheless, the average molecular weights of the maleimide-thiophene copolymers were enhanced through interchain linking of their side-chain groups, thereby enhancing the PV performance of the PSCs based on the maleimide-thiophene copolymers.

In addition to influencing the values of $J_{\mathrm{SC}}$ and $\eta$, the degree of interchain linking of the maleimide-thiophene copolymer also improved the stability of the PV efficiency. Figure 10 reveals the stabilities of the PV efficiencies of the PSCs based on the maleimidethiophene copolymer/PCBM (1:4 (w/w)) blend films. We measured the PV efficiencies of these PSCs under illumination $\left(100 \mathrm{~mW} \mathrm{~cm}^{-2}\right)$ of simulated sunlight from an AM1.5 solar simulator at room temperature. The operational stabilities of the PSCs based on the interchain-linked copolymer/PCBM blends were higher than those of the PSCs based on 2-hydroxyethyl-functionalized copolymer/PCBM blends, as a result of the values of $T_{\mathrm{g}}$ of the interchain-linked copolymers being higher than those of the corresponding $\mathrm{OH}$ containing side-chain copolymers. Moreover, the presence of $\mathrm{OH}$ groups in the photoactive layers of the PSCs led to oxidation of the photoactive layers when the conjugated polymers were charged under an electric field, resulting in lower stability for the PSCs fabricated from the $\mathrm{OH}$-presenting side-chain copolymers. ${ }^{61}$ In addition, during operation of the device, we observed deterioration of the PV performance as a result of the morphological changes of the polymer/PCBM-based photoactive layer. The polymer and PCBM units tended to segregate, with large aggregates of PCBM forming in the film; the PV performance decreased as a result of this phase separation. Therefore, the PSCs fabricated from the interchain-linked polymers having higher values of $T_{\mathrm{g}}$ possessed higher operational stabilities.

\section{CONCLUSIONS}

We have developed a series of side-chain-type maleimide-thiophene copolymers, presenting different contents of pendent 2-hydroxyethyl and 6-hydroxyhexyl units, for PSC applications. We obtained interchain bridge-linked copolymers through the reactions of the $\mathrm{OH}$ groups of the side-chain copolymers with DMBPI. The thermal stabilities of the interchain-linked copolymers were greater than those of the corresponding side-chain copolymers. In addition, the interchain-linked polymers exhibited excellent solubility in $\mathrm{CHO}$. We fabricated a series of PSCs incorporating blends of the fullerene derivative PCBM and either the $\mathrm{OH}$-functionalized or interchainlinked copolymers. The morphology of the photoactive layer and the PV properties of the PSCs were strongly affected by the nature of the pendent functionality and the degree of interchain bridge linking of the conjugated polymers. The PV performances of the PSCs based on the interchain-linked copolymer/PCBM blends were superior to those based on the $\mathrm{OH}$-functionalized copolymer/PCBM blends.

\section{ACKNOWLEDGEMENTS}

We thank the National Science Council of Taiwan, ROC, for financial support.

1 Coakley, K. M. \& McGehee, M. D. Conjugated polymer photovoltaic cells. Chem. Mater 16, 4533-4542 (2004).

2 Cheng, Y. J., Yang, S. H. \& Hsu, C. S. Synthesis of conjugated polymers for organic solar cell applications. Chem. Rev. 109, 5868-5923 (2009).

3 Beaupre, S., Boudreault, P. L. T. \& Leclerc, M. Solar-energy production and energyefficient lighting: photovoltaic devices and white-light-emitting diodes using poly(2,7fluorene), poly(2,7-carbazole), and poly(2,7-dibenzosilole) derivatives. Adv. Energy Mater. 2, E6-E27 (2010).

4 Krebs, F. C., Jorgensen, M., Norrman, K., Hagemann, O., Alstrup, J., Nielsen, T. D., Fyenbo, J., Larsen, K. \& Kristensen, J. A complete process for production of flexible large area polymer solar cells entirely using screen printing-first public demonstration. Sol. Energy Mater. Sol. Cells 93, 422-441 (2009).

5 Tipnis, R., Bernkopf, J., Jia, S., Krieg, J., Li, S., Storch, M. \& Laird, D. Large-area organic photovoltaic module-fabrication and performance. Sol. Energy Mater. Sol. Cells 93, 442-446 (2009).

6 Manceau, M., Angmo, D., Jorgensen, M. \& Krebs, F. C. ITO-free flexible polymer solar cells: from small model devices to roll-to-roll processed large modules. Org. Electron 12, 566-574 (2001)

7 Liang, Y., Xu, Z., Xia, J., Tsai, S. T., Wu, Y., Li, G., Ray, C. \& Yu, L. For the bright future-bulk heterojunction polymer solar cells with power conversion efficiency of 7.4\%. Adv. Mater. 22, E135-E138 (2010).

8 Liang, Y., Feng, D., Wu, Y., Tsai, S. T., Li, G., Ray, C. \& Yu, L. Highly efficient solar cel polymers developed via fine-tuning of structural and electronic properties. J. Am. Chem. Soc. 131, 7792-7799 (2009)

9 Park, S. H., Roy, A., Beaupre, S., Cho, S., Coates, N., Moon, J. S., Moses, D., Leclerc M., Lee, K. \& Heeger, A. J. Bulk heterojunction solar cells with internal quantum efficiency approaching 100\%. Nat. Photonics 3, 297-303 (2009).

10 Liang, Y. \& Yu, L. A new class of semiconducting polymers for bulk heterojunction solar cells with exceptionally high performance. Acc. Chem. Res. 49, 1227-1236 (2010). 
11 Khlyabich, P. P., Burkhart, B., Ng, C. F. \& Thompson, B. C. Efficient solar cells from semi-random P3HT analogues incorporating diketopyrrolopyrrole. Macromolecules 44, 5079-5084 (2011).

12 Hwang, Y. M., Ohshita, J., Harima, Y., Mizumo, T., Ooyama, Y., Morihara, Y., Izawa, T., Sugioka, T. \& Fujita, A. Synthesis, characterization, and photovoltaic applications of dithienogermoledithienylbenzothiadiazole and -dithienylthiazolothiazole copolymers. Polymer (Guildf) 52, 3912-3916 (2011).

13 Zhang, Y., Zou, J., Yip, H. L., Chen, K. S., Davies, J. A., Sun, Y. \& Jen, A. K. Y. Synthesis, characterization, charge transport, and photovoltaic properties of dithienobenzoquinoxaline- and dithienobenzopyridopyrazine-based conjugated polymers. Macromolecules 44, 4752-4758 (2011).

14 Xin, H., Guo, X., Kim, F. S., Ren, G., Watson, M. D. \& Jenekhe, S. A. Efficient solar cells based on a new phthalimide-based donor-acceptor copolymer semiconductor: morphology, charge-transport, and photovoltaic properties. J. Mater. Chem. 19, 5303-5310 (2009).

15 Chang, Y. T., Hsu, S. L., Su, M. H. \& Wei, K. H. Intramolecular donor-acceptor regioregular poly(hexylphenanthrenyl-imidazole thiophene) exhibits enhanced hole mobility for heterojunction solar cell applications. Adv. Mater. 21, 2093-2097 (2009).

16 Zhou, E., Yamakawa, S., Tajima, K., Yang, C. \& Hashimoto, K. Synthesis and photovoltaic properties of diketopyrrolopyrrole-based donor-acceptor copolymers. Chem. Mater. 21, 4055-4061 (2009).

17 Wienk, M. M., Kroon, J. M., Verhees, W. J. H., Knol, J., Hummelen, J. C., Hal, P. A. V. \& Janssen, R. A. J. Efficient methano[70]fullerene/MDMO-PPV bulk heterojunction photovoltaic cells. Angew. Chem. Int. Ed. 42, 3371-3375 (2003).

18 Duren, J. K. J. V., Yang, X., Loos, J., Lieuwma, C. W. T. B., Sieval, A. B., Hummelen, J. C. \& Janssen, R. A. J. Relating the morphology of poly( $p$-phenylene vinylene)/methanofullerene blends to solar-cell performance. Adv. Funct. Mater. 14, 425-434 (2004).

19 Xin, H., Ren, G., Kim, F. S. \& Jenekhe, S. A. Bulk heterojunction solar cells from poly(3 butylthiophene)/fullerene blends: in situ self-assembly of nanowires, morphology, charge transport, and photovoltaic properties. Chem. Mater. 20, 6199-6207 (2008).

20 Svanstrom, C. M. B., Rysz, J., Bernasik, A., Budkowski, A., Zhang, F., Inganas, O., Andersson, M. R., Magnusson, K. O., Smith, J. J. B., Nelson, J. \& Moons, E. Device performance of APFO-3/PCBM solar cells with controlled morphology. Adv. Mater. 21, 4398-4403 (2009).

21 Kim, C. S., Kim, J. B., Lee, S. S., Kim, Y. S. \& Loo, Y. L. Sequence of annealing polymer photoactive layer influences the air stability of inverted solar cells. Org. Electron 10, 1483-1488 (2009).

22 Peet, J., Senatore, M. L., Heeger, A. J. \& Bazan, G. C. The role of processing in the fabrication and optimization of plastic solar cells. Adv. Mater. 21, 1521-1527 (2009).

23 Kawano, K., Sakai, J., Yahiro, M. \& Adachi, C. Effect of solvent on fabrication of active layers in organic solar cells based on poly(3-hexylthiophene) and fullerene derivatives. Sol. Energy Mater. Sol. Cells 93, 514-518 (2009).

24 Chen, H. Y., Hou, J. H., Zhang, S. Q., Liang, Y. Y., Yang, G., Yang, Y., Yu, L. P., Wu, Y. \& $\mathrm{Li}, \mathrm{G}$. Polymer solar cells with enhanced open-circuit voltage and efficiency. Nat. Photonics 3, 649-653 (2009).

25 Huo, L. J., Zhang, S. Q., Guo, X., Xu, F., Li, Y. F. \& Hou, J. H. Replacing alkoxy groups with alkylthienyl groups: a feasible approach to improve the properties of photovoltaic polymers. Angew. Chem. Int. Ed. 50, 9697-9702 (2011).

26 Ryu, M. S., Cha, H. J. \& Jang, J. Improvement of operation lifetime for conjugated polymer:fullerene organic solar cells by introducing a UV absorbing film. Sol. Energy Mater. Sol. Cells 94, 152-156 (2010).

27 Manceau, M., Chambon, S., Rivaton., A., Gardette, J. L., Guillerez, S. \& Lemaitre, N. Effects of long-term UV-visible light irradiation in the absence of oxygen on P3HT and P3HT:PCBM blend. Sol. Energy Mater. Sol. Cells 94, 1572-1577 (2010).

28 Yang, L., Xu, H., Tian, H., Yin, S. \& Zhang, F. Effect of cathode buffer layer on the stability of polymer bulk heterojunction solar cells. Sol. Energy Mater. Sol. Cells 94, 1831 (2010).

29 Sarkar, S., Culp, J. H., Whyland, J. T., Garvan, M. \& Misra, V. Encapsulation of organic solar cells with ultrathin barrier layers deposited by ozone-based atomic layer deposition. Org. Electron 11, 1896-1900 (2010).

30 Schumann, S., Campo, R. D., Illy, B., Cruickshank, A. C. McLachlan, M. A., Ryan, M. P., Riley, D. J., McComb, D. W. \& Jones, T. S. Inverted organic photovoltaic devices with high efficiency and stability based on metal oxide charge extraction layers. J. Mater. Chem. 21, 2381-2386 (2011).

31 Luo, J., Xiao, L., Chen, Z., Qu, B. \& Gong, Q. Insulator MnO: highly efficient and air-stable n-type doping layer for organic photovoltaic cells. Org. Electron 11, 664-669 (2010).

32 Qian, L., Yang, J., Zhou, R., Tang, A., Zheng, Y., Tseng, T. K., Bera, D., Xue, J. \& Holloway, P. H. Hybrid polymer-CdSe solar cells with a ZnO nanoparticle buffer layer for improved efficiency and lifetime. J. Mater. Chem. 21, 3814-3817 (2011).

33 Lee, J. U. I., Jung, J. W., Emrick, T., Russell, T. P. \& Jo, W. H. Synthesis of C60-end capped P3HT and its application for high performance of P3HT/PCBM bulk heterojunction solar cells. J. Mater. Chem. 20, 3287-3294 (2010).

34 Fabiano, S., Chen, Z., Vahedi, S., Facchetti, A., Pignataro, B. \& Loi, M. A. Role of photoactive layer morphology in high fill factor all-polymer bulk heterojunction solar cells. J. Mater. Chem. 21, 5891-5896 (2011).

35 Wang, J. C., Lu, C. Y., Hsu, J. L., Lee, M. K., Hong, Y. R., Perng, T. S., Horng, S. F. \& Meng, H. F. Efficient inverted organic solar cells without an electron selective layer. J. Mater. Chem. 21, 5723-5728 (2011).

36 Li, H., Tang, H., Li, L., Xu, W., Zhao, X. \& Yang, X. Solvent-soaking treatment induced morphology evolution in P3HT/PCBM composite films. J. Mater. Chem. 21, 6563-6568 (2011).
37 Yang, X., Duren, J. K. J., Rispens, M. R., Hummelen, J. C., Janssen, R. A. J., Michels, M. A. J. \& Loos, J. Crystalline organization of a methanofullerene as used for plastic solar cell application. Adv. Mater. 16, 802-806 (2004).

38 Yang, X., Duren, J. K. J., Janssen, R. A. J., Michels, M. A. J. \& Loos, J. Morphology and thermal stability of the active layer in poly( $p$-phenylenevinylene)/methanofullerene plastic photovoltaic devices. Macromolecules 37, 2151-2158 (2004).

39 Bertho, S., Janssen, G., Cleij, T. J., Conings, B., Moons, W., Gadisa, A., D'Haen, J., Goovaerts, E., Lutsen, L., Manca, J. \& Vanderzande, D. Effect of temperature on the morphological and photovoltaic stability of bulk heterojunction polymer:fullerene solar cells. Sol. Energy Mater. Sol. Cells 92, 753-760 (2008).

40 Drees, M., Hoppe, H., Winder, C., Neugebauer, H., Sariciftci, N. S., Schwinger, W., Schaffler, F., Topf, C., Scharber, M. C., Zhu, Z. \& Gaudiana, R. Stabilization of the nanomorphology of polymer-fullerene 'bulk heterojunction' blends using a novel polymerizable fullerene derivative. J. Mater. Chem. 15, 5158-5163 (2005).

41 Zhu, Z., Hadjikyriacou, S., Waller, D. \& Gaudiana, R. Stabilization of film morphology in polymer-fullerene heterojunction solar cells. J. Macromol. Sci. A A41, 1467-1487 (2004),

42 Hsieh, C. H., Cheng, Y. J., Li, P. J., Chen, C. H., Dubosc, M., Liang, R. M. \& Hsu, C. S. Highly efficient and stable inverted polymer solar cells integrated with a cross-linked fullerene material as an interlayer. J. Am. Chem. Soc. 132, 4887-4893 (2010).

43 Cheng, Y. J., Hsieh, C., He, Y. J., Hsu, C. H. \& Li, Y. F. Combination of indene-C60 bisadduct and cross-linked fullerene interlayer leading to highly efficient inverted polymer solar cells. J. Am. Chem. Soc. 132, 17381-17383 (2010).

44 Chang, C. Y., Wu, C. E., Chen, S. Y., Cui, C. H., Cheng, Y. J., Hsu, C. H., Wang, Y. L. \& $\mathrm{Li}, \mathrm{Y}$. F. Enhanced performance and stability of a polymer solar cell by incorporation of vertically aligned, cross-linked fullerene nanorods. Angew. Chem. Int. Ed. 50, 9386-9390 (2011).

45 Miyanishi, S., Tajima, K. \& Hashimoto, K. Morphological stabilization of polymer photovoltaic cells by using cross-linkable poly(3-(5-hexenyl)thiophene). Macromolecules 42, 1610-1618 (2009).

46 Farinhas, J., Ferreira, Q., Paolo, R. E. D., Alcacer, L., Morgado, J. \& Charas, A. Nanostructured donor/acceptor interfaces in photovoltaic cells using columnar-grain films of a cross-linked poly(fluorene-alt-bithiophene). J. Mater. Chem. 21, 12511-12519 (2011).

47 Lee, U. R., Lee, T. W., Hoang, M. H., Kang, N. S., Yu, J. W., Kim, K. H., Lim, K. G., Lee, T. W., Jin, J. I. \& Choi, D. H. Photoreactive low-bandgap 4H-cyclopenta[2, $\left.1-b: 3,4-b^{\prime}\right]$ dithiophene and 4,7-di(thiophen-2-yl)benzo[c][1,2,5]thiadiazole-based alternating copolymer for polymer solar cell. Org. Electron 12, 269-278 (2011).

48 Zhou, E., Tan, Z., Yang, Y., Huo, L. J., Zou, Y. P., Yang, C. H. \& Li, Y. F. Synthesis, hole mobility, and photovoltaic properties of cross-linked polythiophenes with vinyleneterthiophene-vinylene as conjugated bridge. Macromolecules 40, 1831-1837 (2007).

49 Tu, G., Bilge, A., Adamczyk, S., Forster, M., Heiderhoff, R., Balk, L. J., Muhlbacher, D., Morana, M., Koppe, M., Scharber, M. C., Choulis, S. A., Brabec, C. J. \& Scherf, U. The influence of interchain branches on solid state packing, hole mobility and photovoltaic properties of poly(3-hexylthiophene) (P3HT). Macromol. Rapid. Commun. 28, 17811785 (2007).

50 Lee, R. H. \& Lee, L. Y. Photovoltaic properties of bulk heterojunction solar cells incorporating 2-hydroxylethyl- and fullerene-functionalized conjugated polymers. Colloid. Polym. Sci. 289, 1215-1231 (2011).

51 Liu, T. Z. \& Chen, Y. Synthesis, optical and electrochemical properties of luminescent polymers containing 1,2-diphenylmaleimide and thiophene segments. Polymer (Guildf) 46, 10383-10391 (2005)

52 Chan, L. H., Lee, Y. D. \& Chen, C. T. Synthesis and characterization of 3,4diphenylmaleimide copolymers that exhibitorange to red photoluminescence and electroluminescence. Macromolecules 39, 3262-3269 (2006).

53 Hou, J. H., Tan, Z. A., He, Y. J., Yang, C. H. \& Li, Y. F. Branched poly(thienylene vinylene)s with absorption spectra covering the whole visible region. Macromolecules 39, 4657-4662 (2006).

54 Lee, J. Y., Park, S. M. \& Jung, W. T. Synthesis and nonlinear optical properties of novel polyurethanes with high thermal stability for electro-optic applications. Bull. Korean Chem. Soc. 26, 841-844 (2005).

55 Li, Y. W., Xue, L. L., Xia, H. J., Xu, B., Wen, S. P. \& Tian, W. J. Synthesis and properties of polythiophene derivatives containing triphenylamine moiety and their photovoltaic applications. J. Polym. Sci. Polym. Chem. 46, 3970-3984 (2008).

56 Sariciftci, N. S., Smilowitz, L., Heeger, A. J. \& Wudl, F. Photoinduced electron transfer from a conducting polymer to buckminsterfullerene. Science 258, 1474-1476 (1992).

$57 \mathrm{Yu}$, G., Zhang, C. \& Heeger, A. J. Dual-function semiconducting polymer devices: light-emitting and photodetecting diodes. Appl. Phys. Lett. 64, 1540-1542 (1994).

58 Gao, F., Hide, F. \& Wang, H. Efficient photodetectors and photovoltaic cells from composite of fullerenes and conjugated polymers: photoinduced electron transfer.. Synth. Met. 84, 979-980 (1997).

59 Kim, H., Kim, J. Y., Lee, K., Park, Y., Jin, Y. \& Suh, H. Organic photovoltaic cells base on conjugated polymer/fullerene composites. Curr. Appl. Phys. 1, 139-143 (2001).

60 Vandewal, K., Gadisa, A., Oosterbaan, W. D., Bertho, S., Banishoeib, F., Severen, I. V., Lutsen, L., Cleij, T. J., Vanderzande, D. \& Manca, J. V. The relation between open-circuit voltage and the onset of photocurrent generation by charge-transfer absorption in polymer: fullerene bulk heterojunction solar cells. Adv. Funct. Mater. 18, 2064-2070 (2008).

$61 \mathrm{Hsieh}, \mathrm{B} . \mathrm{R}$., Ettedgui, E. \& Gao, Y. The surface species of poly( $p$-phenylene vinylene) and their effect on metal interface formation. Synth. Met. 78, 269-275 (1996).

62 Li, Y. F. \& Zou, Y. P. Conjugated polymer photovoltaic materials with broad absorption band and high charge carrier mobility. Adv. Mater. 20, 2952-2958 (2008). 